\title{
Review \\ Current Status of Angiogenic Cell Therapy and Related Strategies Applied in Critical Limb Ischemia
}

\author{
Lucía Beltrán-Camacho ${ }^{1,2,+} \mathbb{D}$, Marta Rojas-Torres ${ }^{1,2,+}$ and $M^{a}$ Carmen Durán-Ruiz ${ }^{1,2, *}$ \\ 1 Biomedicine, Biotechnology and Public Health Department, Cádiz University, 11519 Cadiz, Spain; \\ lucia.beltrancamacho@alum.uca.es (L.B.-C.); marta.rojas@uca.es (M.R.-T.) \\ 2 Institute of Research and Innovation in Biomedical Sciences of Cadiz (INIBICA), 11009 Cádiz, Spain \\ * Correspondence: maricarmen.duran@gm.uca.es; Tel.: +34-956-012-727 \\ + These authors contributed equally to this work.
}

Citation: Beltrán-Camacho, L. Rojas-Torres, M.; Durán-Ruiz, M.C. Current Status of Angiogenic Cell Therapy and Related Strategies Applied in Critical Limb Ischemia. Int. J. Mol. Sci. 2021, 22, 2335. https://doi.org/doi:10.3390/ ijms22052335

Academic Editor: Paul Quax

Received: 7 January 2021

Accepted: 23 February 2021

Published: 26 February 2021

Publisher's Note: MDPI stays neutral with regard to jurisdictional claims in published maps and institutional affiliations.

Copyright: (c) 2021 by the authors. Licensee MDPI, Basel, Switzerland. This article is an open access article distributed under the terms and conditions of the Creative Commons Attribution (CC BY) license (https:// creativecommons.org/licenses/by/ $4.0 /)$

\begin{abstract}
Critical limb ischemia (CLI) constitutes the most severe form of peripheral arterial disease (PAD), it is characterized by progressive blockade of arterial vessels, commonly correlated to atherosclerosis. Currently, revascularization strategies (bypass grafting, angioplasty) remain the first option for CLI patients, although less than $45 \%$ of them are eligible for surgical intervention mainly due to associated comorbidities. Moreover, patients usually require amputation in the short-term. Angiogenic cell therapy has arisen as a promising alternative for these "no-option" patients, with many studies demonstrating the potential of stem cells to enhance revascularization by promoting vessel formation and blood flow recovery in ischemic tissues. Herein, we provide an overview of studies focused on the use of angiogenic cell therapies in CLI in the last years, from approaches testing different cell types in animal/pre-clinical models of CLI, to the clinical trials currently under evaluation. Furthermore, recent alternatives related to stem cell therapies such as the use of secretomes, exosomes, or even microRNA, will be also described.
\end{abstract}

Keywords: critical limb ischemia; neovascularization; angiogenesis; arteriogenesis; cell therapy; secretomes

\section{Critical Limb Ischemia}

Critical Limb Ischemia (CLI) constitutes the most severe form of Peripheral Arterial Disease (PAD), a prevalent manifestation of atherosclerosis which involves the blockade of major systemic arteries other than those of the cerebral and coronary circulation [1], more common in legs than in arms [2]. PAD affects around 10-15\% of adults, being an underestimated and underdiagnosed cardiovascular disease (CVD) due to its asymptomatic initial stages [3]. PAD is associated with risk factors such as older age, hypertension, dyslipidemia, or smoking [4], and it is more prevalent in diabetic people due to metabolic alterations such as angiogenesis impairment, inflammatory progression, or endothelial dysfunction [5-8]. CLI itself has an annual incidence of $0.35 \%$ and an average prevalence of $1.33 \%$, affecting to 500-1000 people per 1 million population in Europe and the United States [9]. CLI patients are classified based on clinical criteria and hemodynamic parameters (i.e., pulse volume recordings, ankle and toe pressure values, rest pain, and tissue loss) [10-12] currently accepted in international consensus guidelines on PAD and CLI [12-16]. Overall, CLI patients suffer from chronic ischemic rest pain, ulcers, or gangrene, as well as an increased risk of cardiovascular events. CLI has a huge impact on the patients' quality of life, being associated with an increased risk of amputations (fingers, toes, or extremities) and, moreover, an increase in mortality rates [15,17-20]. This debilitating disease causes high dependency on caregivers, requiring permanent local wound treatment, and the chronic use of pain-relieving medications, considerably diminishing patient's quality of life [21].

Nowadays, the treatment of CLI remains highly variable and, in many situations, suboptimal [22]. Initial recommendations for CLI patients to prevent further cardiovascular 
events include smoking cessation, lipid lowering (statins mainly), antiplatelet therapies, or ACE inhibitors [16]. Alternatively, other medical strategies or pharmaceutical agents have been applied for the specific treatment of CLI patients (sympathectomy or spinal cord stimulation, iloprost) [23]. Unfortunately, these strategies do not seem to be totally effective in reducing limb-specific events [16], although larger studies/clinical trials are required in order to reach definitive conclusions.

The majority of CLI patients require revascularization interventions like bypass or angioplasty, having observed a significant improvement in the techniques and devices applied (cryoplasty, stent-grafts, drug-eluting balloons or stents, etc.) in the past decades. Nevertheless, the percentage of patients eligible for these strategies is not higher than $45 \%$ due to high comorbidity or surgical related issues such as difficult access due to narrow vessels, etc. Furthermore, patients that undergo surgery will usually require amputation at the short term [24]. Amputation rates are unacceptably high, typically exceeding $15-20 \%$ at 1 year and can vary by the presence of comorbid conditions [25] such as diabetes mellitus (DM), which elevates this rate up to 50\% in CLI diabetic patients [26]. Diabetic patients have higher risk of suffering PAD/CLI and a negative outcome partly related to the abrogation of new vessel formation and remodeling of the pre-existing vasculature under hyperglycemic conditions [27]. Unfortunately, the increasing prevalence of PAD together with higher presence of other CLI risk factors (i.e., diabetes) and the rising number of people in advanced age provide little reason to believe that the number of patients suffering this disease will decrease in the near future [25]. The poor prognosis of CLI patients as well as their impaired quality of life makes compulsory to find effective and less invasive treatments. Moreover, the desirable treatment should be applicable to all CLI patients, because the actual percentage of ineligible patients is unacceptably high.

As an alternative to conventional treatments, therapeutic angiogenesis has arisen as a promising treatment for CLI patients, mainly those considered as "no-option", due to the potential of this strategy to promote revascularization of ischemic tissues [28-33]. To date, different approaches including angiogenic gene or cell-based therapies are currently under investigation.

In this review, we have mainly focused on the use of angiogenic cell therapy for CLI (Figure 1), from animal/pre-clinical models designed to study CLI and the tools applied to test for revascularization in response to cell therapy, to the angiogenic therapies currently under evaluation in clinical trials. Moreover, recent alternatives derived from stem cell therapies, such as the use of secretomes, exosomes, or even microRNAs, will be described.

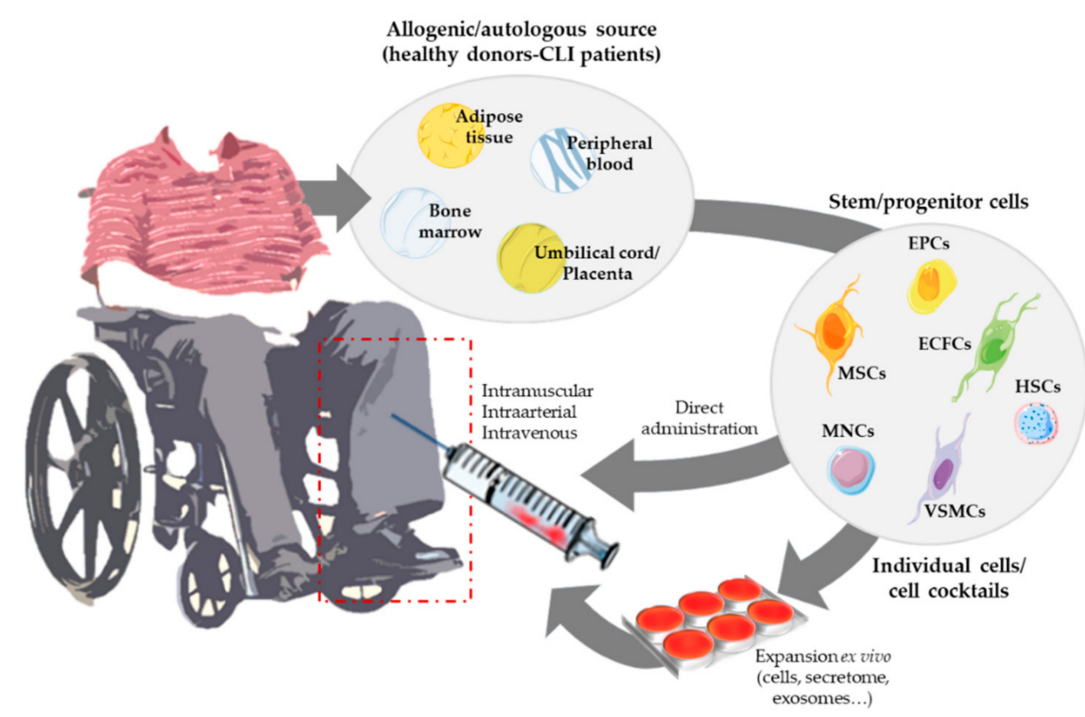

Figure 1. Overview of angiogenic cell therapy for Critical Limb Ischemia (CLI). 


\section{Animal Models of CLI}

CLI animal models are not only used to study the disease itself [34,35], they also provide the appropriate scenario to evaluate strategies to induce neovascularization or to reduce inflammatory response. These models allow us to follow-up cell mobilization in response to ischemia [36-39]. Moreover, biodistribution assays are essential to determine the cell's fate $[40,41]$ and more importantly, to evaluate the biosafety profile, being required by regulatory guidelines prior to initiating cell therapy into the clinic [42]. Furthermore, for treatments testing human components such as human cells, immunosuppressed animals (nude, athymic, etc.) are usually applied [43].

Thus, in order to pre-clinically evaluate the effect of cell therapy on revascularization, it becomes essential first to be able to achieve an optimal model of CLI capable to resemble as much as possible the characteristics found in humans. Until now, femoral artery ligation (FAL) remains the most common approach to induce CLI, which is usually performed in one limb, leaving the other as a non-ischemic control. Several studies performing single or double femoral ligation, or alternatively cutting the femoral artery in different sites or even excision of the artery (partly or in all branches) can be found, creating different grades of CLI $[44,45]$ (Figure 2). Additionally, depending on the occlusion site, extent of the injury or the occlusion tools (suture knots, constrictors, electrocoagulation, etc.), it is possible to create different degrees of the disease, causing different ischemic stages and patterns of perfusion restoration $[43,46]$.
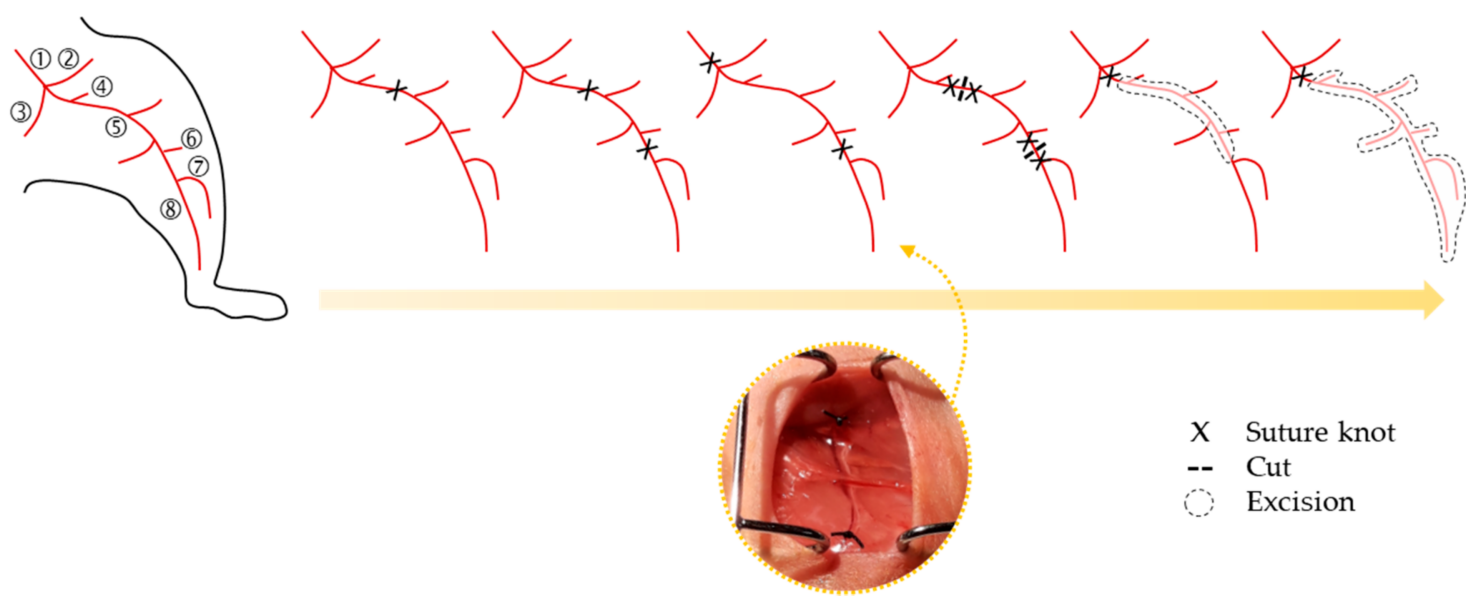

X Suture knot

-- Cut

Excision

Figure 2. Schematic representation of femoral artery ligation (FAL) strategies usually applied to create PAD/CLI models, from the lowest (left) to the highest (right) severity models of the disease. A representative image of the FAL strategy followed in our research group is also shown [41,47]. Legend: (1) Iliac artery, (2) Iliacofemoral artery, (3) Internal iliac artery, (4) Pudendoepigastric trunk, (5) Femoral artery and its branches (lateral circumflex and proximal caudal), (6) Superficial caudal epigastric artery, (7) Popliteal artery, and (8) Saphenous artery. Arterial anatomy information was based on Kochi et al. [48].

The resulting CLI model not only depends on the methods described to promote ischemia, but also on the operator performing the interventions, the animals used (mouse, rat, rabbit, pig, etc.), or even the strain selected [49-51]. Moreover, it is difficult to reproduce an animal model that resembles $100 \%$ CLI in humans, as this disease courses with a very slow progression, without important or aggressive symptoms for years, until becomes chronic. In this regard, Lejay et al. proposed a sequential ligation process, ligating first the femoral artery and days after the iliac artery, in order to achieve a progressive model and with similar impaired functions than patients [52]. Krishna et al. performed a "twostage model", with an initial arterial narrowing using ameroid constrictors over 14 days, prior to the induction of acute ischemia by FAL and excision [53]. Similarly, Han et al. created a model with local thrombosis in vessels by photochemical reaction triggered by the administration of erythrosine $B$, modifying endothelial function and occluding the vessels lumen by the blood clot, therefore getting closer to the human pathology than ligation [54]. 
On the other hand, the fact that most studies use healthy animals to generate CLI models constitutes an issue itself. CLI patients present, among other characteristics, endothelial dysfunction or reduced vascularity, which correlate with impaired vascular recovery. In FAL models, however, the vascular regeneration properties remain intact, which removes us from the reality of the patients' symptoms. Moreover, autologous cell therapy appears to be less effective than expected because cells show impaired functions under pathological conditions. For that reason, researchers have tried to combine FAL with additional strategies to replicate the pathophysiological characteristics found in CLI patients. Parikh et al. combined FAL with endothelial nitric oxide synthase (eNOS) inhibitor administration, increasing vasoconstriction and ischemia by blocking nitric oxide (NO) production [55]. Alternatively, animal models presenting risk factors associated with PAD, such as hyperlipidemia, hypercholesterolemia, or diabetes, have also been employed. Thus, CLI models generated in hyperlipidemic and diabetic mice generally coursed with reduced collateral formation and blood flow recovery, showing better correlation with human patients [56]. Apolipoprotein E (ApoE)-deficient mice, commonly accepted as a model of atherosclerosis [4], also show a decrease of muscle regeneration after FAL surgery [37].

\section{Strategies Followed to Assess Neovascularization in CLI}

The ultimate goal of any CLI treatment is to promote post-natal neovascularization, a repairing mechanism that takes place in response to ischemic events as an strategy to recover the damaged tissues and provide sufficient oxygen and nutrient supply to ensure tissue surveillance [57]. In adults, neovascularization comprises both angiogenesis and arteriogenesis, processes in which different types of vascular and immune cells participate [58]. Angiogenesis consists in the formation of new blood vessels from existing ones, while arteriogenesis involves collateral growth and remodeling of pre-existing arterioles to generate larger conductance vessels and to compensate for the loss of blood flow of occluded arteries (Figure 3a) [59]. Remarkably, FAL animal models and patients usually show similar neovascularization patterns, with enhanced arteriogenesis next to the occlusion site and increased angiogenesis in the distal ischemic tissue [49]. Thus, therapeutic strategies should seek the stimulation of both processes in order to promote neovascularization [58].

(a)

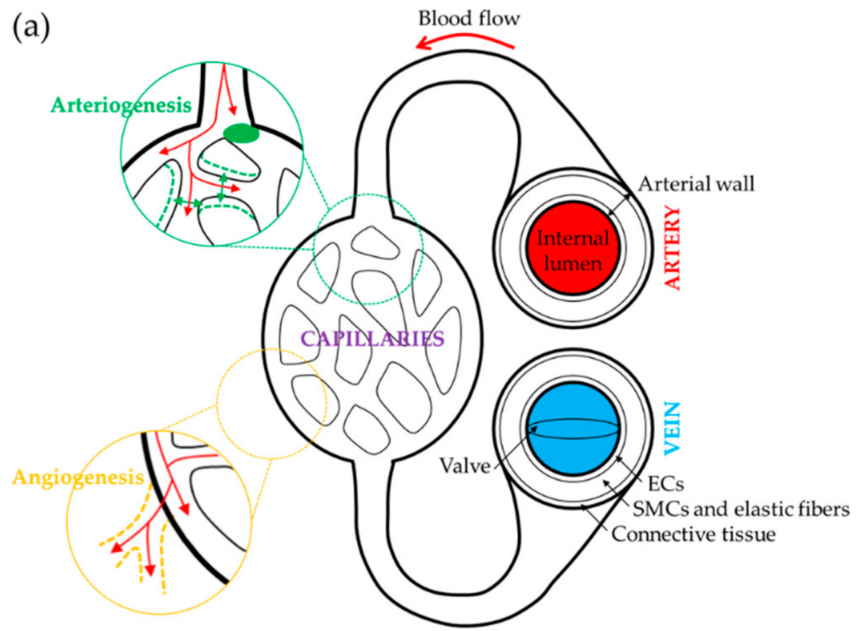

(b)

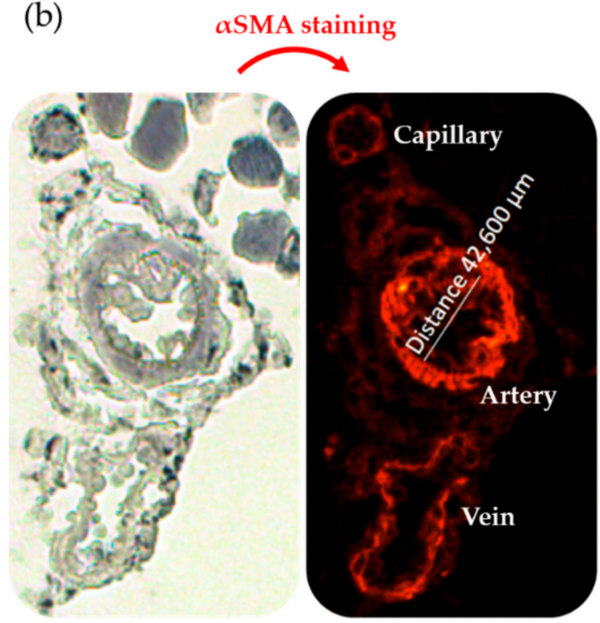

Figure 3. Mechanisms of neovascularization. (a) Schematic representation of the circulatory system in which angiogenesis and arteriogenesis processes are represented. (b) Representative immunohistochemistry image of blood vessels detected in the low back muscle of a CLI mouse [47], to evaluate vascular density and diameter size using anti-smooth muscle $\alpha$-actin $(\alpha-S M A$, red) antibody.

In studies involving CLI animal models (Table 1), different strategies are usually applied to analyze potential neovascularization. Blood flow recovery over time is often analyzed by Laser Doppler Perfusion (LDP). This technology is based on Doppler effect, 
consisting in the alteration of a wave's frequency as result of the movement between a laser light and circulating red blood cells. Alternatively, the LDP Imaging system creates images from blood perfusion values per pixel, getting a map of the blood flow in the region of interest [49]. In FAL-based studies, perfusion is measured before and after surgical intervention, and then registered during several days, usually 3-4 weeks. Perfusion data are normally shown as blood flow ratios (ischemic limb/healthy limb). Although there are other techniques to evaluate collateral formation and limb perfusion such as X-ray microangiography [49], LDP has been the most applied tool in recent publications due to the easy handling of the equipment and, moreover, because it constitutes a noninvasive method.

Histological analysis by immunohistochemistry (IHC) is also used to evaluate angiogenesis and arteriogenesis post-mortem. Most studies use anti- $\alpha$ smooth muscle actin antibodies to identify blood vessels in tissues (Figure $3 b$ ), together with antibodies against endothelial cells markers, such as CD31, von Willebrand factor, or lectins with specific affinity for endothelial cells, like Ulex europaeus agglutinin I in humans or Griffonia simplicifolia lectin I isolectin B4 in non-primates [47,49,60,61]. For angiogenesis, vascular density is calculated by counting the number of blood vessels, and capillary diameters are measured for arteriogenesis evaluation. The internal lumen's diameter is normally measured to evaluate arteriogenesis, although the arterial wall area is also interesting since arteriogenesis increases diameter and wall thickness $[59,62]$. Results are usually expressed as the number of blood vessels per $\mathrm{mm}^{2}$ in angiogenesis and blood vessel diameter $(\mu \mathrm{m})$ or area $\left(\mu \mathrm{m}^{2}\right)$ in arteriogenesis. Alternatively, another method to study angiogenesis is an in vivo matrigel plug assay, consisting in the injection of matrigel or similar hidrogels containing specific cell types into the subcutaneous space [63]. After several days of post-implantation, mice are sacrificed and the matrigel plugs are extracted and excised for further analysis. Sections can be then stained to identify capillary structures, and vasculature growth into matrigel provides information regarding angiogenesis [49].

\section{Angiogenic Cell Therapy}

Angiogenic therapy involves the use of angiogenic growth factors (VEGF, HIF-1a, FGF1, HGF, etc.) [33,64], gene transfer techniques using viral or non-viral vectors to transport a gene codifying for a therapeutic protein to the target tissues [65] or, alternatively, the use of angiogenic stem cells. All these strategies aim to improve revascularization by increasing the number/size of blood vessels, promoting blood flow recovery and therefore increasing tissue perfusion in the ischemic extremities [65]. Among them, cell-based therapies seem more efficient compared to protein- or gene-based approaches, not only because of their direct vasculogenic properties, but also due to their paracrine effect. Angiogenic cells can directly participate in the formation of new vessels, while in parallel they also provide endogenous growth factors, promoting vascular growth by paracrine fashion $[66,67]$.

Thus, neovascularization can also be promoted by vasculogenesis, the novo formation of vessels mediated by circulating progenitors or stem cells [59]. Vasculogenesis was initially considered as an embryogenic process. However, post-natal vasculogenesis can also take place by incorporation of vascular stem or progenitor cells into vessel structures, allowing the formation of adult blood vessels [68]. To date, several strategies based on the use of stem and progenitor cells are being tested (Table 1), to promote vasculogenesis but also angiogenesis and arteriogenesis. The safety and efficacy of cell implantation therapies make of this less invasive treatment a feasible option for CLI patients. 


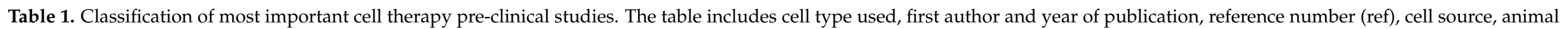

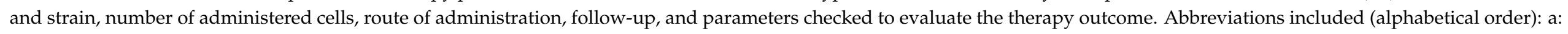

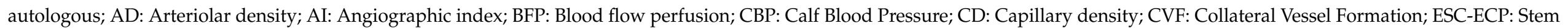

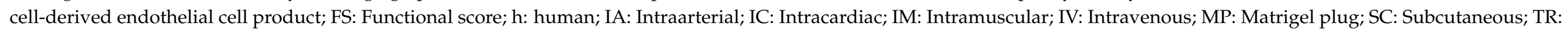
Tissue regeneration; VD: Vessel diameter; VIP: Vascular intersection percentage; VS: Visual Scale

\begin{tabular}{|c|c|c|c|c|c|c|c|c|}
\hline Cell Type & Author (Year) & Ref. & Cell Source & Animal (Strain) & $\begin{array}{l}\text { Administration } \\
\left(\times 10^{5} \text { Cells }\right)\end{array}$ & $\begin{array}{c}\text { Route of } \\
\text { Administration }\end{array}$ & $\begin{array}{l}\text { Follow-up } \\
\text { (Weeks) }\end{array}$ & Outcome \\
\hline aMSCs & Cunha (2013) & [69] & Bone marrow & Mice (Balb-C \& C57 /BL6) & 5 & IM & 4 & $\mathrm{VS}, \mathrm{CD}, \mathrm{TR}$ \\
\hline hMSCs & García-Vazquez (2019) & [70] & Adipose tissue & Mice (Athymic nude) & 6 & IM & 3 & $\mathrm{BFP}, \mathrm{CD}, \mathrm{VS}$ \\
\hline aMSCs & Nammian (2021) & [71] & $\begin{array}{l}\text { Bone marrow \& } \\
\text { adipose tissue }\end{array}$ & Mice (C57 /BL6) & 5 & $\mathrm{IM}$ & 4 & FS, CD \\
\hline hMSCs + hECFCs & Rossi (2017) & [72] & $\begin{array}{l}\text { Bone marrow \& } \\
\text { peripheral blood }\end{array}$ & Mice (Athymic nude) & $\mathrm{N} / \mathrm{A}$ & IV & 2 & $\mathrm{BFP}, \mathrm{CD}, \mathrm{VS}$ \\
\hline hCD34+ & Lian (2018) & [73] & Peripheral blood & Mice (Balb-C Nude) & 1 & $\mathrm{IM}$ & 3 & FS, VS \\
\hline hEPCs & Kalka (2000) & [74] & Peripheral blood & Mice (Athymic nude) & 5 & IC & 4 & $\mathrm{BFP}, \mathrm{CD}, \mathrm{VS}$ \\
\hline hEPCs & Urbich (2003) & [75] & Peripheral blood & $\begin{array}{c}\text { Mice (Athymic NMRI } \\
\text { Nude) }\end{array}$ & 5 & IV & 2 & $\mathrm{BFP}, \mathrm{CD}$ \\
\hline hEPCs & Zhao (2016) & [76] & Fetal aorta & Rat (Goto-Kakizaki) & 100 & IM & 8 & $\mathrm{BFP}, \mathrm{CD}, \mathrm{VS}$ \\
\hline hCACs & Beltrán-Camacho (2020) & [47] & Peripheral blood & Mice (Balb-C Nude) & 5 & IM & 4 days & $\mathrm{BFP}, \mathrm{CD}, \mathrm{FS}, \mathrm{VD}$ \\
\hline hEPCs + hOECs & Yoon (2005) & [77] & Peripheral blood & Mice (Athymic nude) & 2 & $\mathrm{IM}$ & 3 & $\mathrm{BFP}, \mathrm{CD}, \mathrm{VS}, \mathrm{MI}$ \\
\hline hESC-ECP & MacAskill (2018) & {$[40]$} & hESC line & $\begin{array}{l}\text { Mice (CD1-STZ DM } \\
\text { inductor) }\end{array}$ & 10 & $\mathrm{IM}$ & 3 & $\mathrm{BFP}, \mathrm{CD}$ \\
\hline aBM-MNCs & Shintani (2001) & [79] & Bone marrow & $\begin{array}{c}\text { Rabbit (Male New Zealand } \\
\text { White) }\end{array}$ & 5 & $\mathrm{IM}$ & 4 & $\begin{array}{l}\mathrm{BFP}, \mathrm{CBP}, \mathrm{CD}, \\
\mathrm{CVF}\end{array}$ \\
\hline aBMCs & De Nigris (2007) & [80] & Bone marrow & Mice (ApoE-/-) & 20 & IV & 2 & $\mathrm{BFP}, \mathrm{CD}, \mathrm{CVF}$ \\
\hline aBM-MNCs & Jeon (2007) & [81] & Bone marrow & Mice (C57/BL6) & 20 & IM & 4 & $\mathrm{CD}, \mathrm{CVF}$ \\
\hline aBM-MNCs & Gan (2009) & [82] & Bone marrow & Mice (C57/BL6) & 30 & IM & 2 & $\mathrm{BFP}, \mathrm{CD}$ \\
\hline hBM-NCs & Liu (2009) & [83] & Bone marrow & Mice (C57 / BL6 ApoE-/-) & 250 & IA & 4 & $\mathrm{BFP}, \mathrm{CVF}$ \\
\hline
\end{tabular}


Table 1. Cont.

\begin{tabular}{|c|c|c|c|c|c|c|c|c|}
\hline Cell Type & Author (Year) & Ref. & Cell Source & Animal (Strain) & $\begin{array}{l}\text { Administration } \\
\left(\times 10^{5} \text { Cells }\right)\end{array}$ & $\begin{array}{c}\text { Route of } \\
\text { Administration }\end{array}$ & $\begin{array}{l}\text { Follow-up } \\
\text { (Weeks) }\end{array}$ & Outcome \\
\hline aBM-MNCs & Brenes (2012) & [84] & Bone marrow & Mice (C57/BL6) & $5,10 \& 20$ & IM & 4 & $\mathrm{BFP}, \mathrm{CD}, \mathrm{FS}$ \\
\hline aBM-MNCs & Reis (2014) & [85] & Bone marrow & Mice (Balb-C) & 5 & IM & 4 & $\mathrm{CD}, \mathrm{TR}, \mathrm{VS}$ \\
\hline hBM-MNCs & Rojas-Torres (2020) & [41] & Bone marrow & Mice (Balb-C Nude) & 10 & IM & 3 & $\mathrm{BFP}, \mathrm{CD}, \mathrm{FS}, \mathrm{VD}$ \\
\hline $\begin{array}{c}\text { aBMC-derived } \\
\text { macrophages }\end{array}$ & Kuwahara (2014) & [86] & Bone marrow & Mice (C57 / BL6N) & 1 & $\mathrm{IM}$ & 4 & $\mathrm{BFP}, \mathrm{CD}$ \\
\hline aMIAMI cells & Rahnemai-Azar (2011) & [88] & Bone marrow & Mice (Balb-C) & 10 & IM & 4 & $\mathrm{BFP}, \mathrm{CD}, \mathrm{FS}, \mathrm{VS}$ \\
\hline hPB-MNCs ${ }^{1}$ & Li (2006) & [89] & Peripheral blood & Mice (Athymic nude) & 10 & $\mathrm{IM}$ & 4 & $\mathrm{BFP}, \mathrm{AI}, \mathrm{CD}, \mathrm{VS}$ \\
\hline aPB-MNCs + PRP & Padilla (2020) & [90] & Peripheral blood & Rat (Wistar) & 15 & $\mathrm{IM}$ & 4 & AI, VIP \\
\hline aASCs & Liu (2020) & [91] & Adipose tissue & Mice (C57/BL6) & 10 & IM & 3 & $\mathrm{BFP}, \mathrm{CD}, \mathrm{VS}$ \\
\hline $\begin{array}{c}\text { aASCs + } \\
\text { macrophages }\end{array}$ & Rybalko (2017) & [92] & Adipose tissue & Mice (C57/BL6) & 2 & IM & 3 & $\mathrm{BFP}, \mathrm{CD}$ \\
\hline $\begin{array}{c}\text { PDX-PAD } \\
\text { (adherent stromal } \\
\text { cells) }\end{array}$ & Prather (2009) & [94] & Placenta & Mice (Balb-C) & 10 & $\mathrm{IM}$ & 3 & $\mathrm{BFP}, \mathrm{CD}, \mathrm{FS}$ \\
\hline $\begin{array}{c}\text { PLX-PAD } \\
\text { (MSC like stromal } \\
\text { cells) }\end{array}$ & Zahavi-Goldstein (2017) & [95] & Placenta & Mice (C57/BL6) & $0.02-10$ & IM \& SC & 3 & BFP, VS \\
\hline
\end{tabular}




\subsection{Cell Therapies Based on Single or Combined Isolated Cells}

Mesenchymal stem cells (MSCs) are the most used cells in advanced therapies for CVDs [96]. MSCs can be isolated from bone marrow, peripheral blood, or adipose tissues, and from them we can obtain osteoblasts, chondrocytes, adipocytes, neurons, endothelial cells (ECs), skeletal muscle cells, and vascular smooth muscle cells (VSMCs) [97]. MSCs are reported to promote angiogenesis because of their capacity to induce ECs proliferation, migration, and tube formation, while decreasing apoptosis and fibrosis [96,98,99]. Furthermore, MSCs support neoangiogenesis, releasing soluble factors that contribute to stimulate angiogenesis [100]. These cells are thought to improve hind limb ischemia by secreting cytokines that regulate macrophage differentiation to M2, an anti-inflammatory phenotype [101]. Likewise, apart from MSCs, endothelial progenitor cells (EPCs) also represent an important group of cells used in vascular regeneration. In 1997, Asahara et al. demonstrated that CD34+ cells can be isolated from peripheral blood mononuclear cells (PB-MNCs) and differentiated in vitro into ECs, showing the potential use for collateral vessel growth augmentation in ischemic tissues [102]. Although CD34 is not a specific marker of a single cell type, it is mostly associated to EPCs. Many researchers have explored the potential of using EPCs in tissue engineering as an angiogenic source for vascular repairing $[103,104]$. In the past years, several isolation and culturing techniques for EPCs have been described. Besides, the controversy regarding the definition of EPC phenotypes remains, with different studies still presenting a variety of results in terms of surface-based EPC markers $[47,103,105,106]$. At least, two different sub-populations have been accepted and clearly defined, based on their differentiation status and the capability to form colonies: early EPCs (eEPCs) also named circulating angiogenic cells (CACs) or myeloid angiogenic cells (MACs), with hematopoietic phenotype, and late EPCs or endothelial colony forming cells (ECFCs), with endothelial phenotype [106]. EPCs have been thought to derive from hematopoietic stem cells (HSCs), some EPCs could be derived from a niche close to the vasa vasorum in the macro-vascular wall [107]. Despite the controversy regarding the nature of these cells, no one denies the potential of EPCs to promote therapeutic angiogenesis and neovascularization of ischemic tissues [73,74,107]. Overall, in response to injury, cytokines and growth factors mobilize EPCs from the bone marrow into the peripheral blood, which will then participate in neovascularization [73]. Very recently, we have shown how, first days after administration of CACs to ischemic CLI mice, these cells migrate into the ischemic tissues, modulating immune cells recruitment and promoting an increase of angiogenesis and arteriogenesis [47]. However, the administered cells do not remain in the ischemic tissues over time suggesting that they may promote vasculogenesis in a paracrine form $[47,108]$. Moreover, early EPCs do not seem to differentiate to ECs, with this role being assigned to ECFCs [106,109]. Indeed, different studies support that the regenerative properties of eEPCs are mainly due to paracrine effects, while ECFCs present vessel-forming activity in vivo $[47,109]$. Thus, a cell therapy mediated by both cell types, early, and late EPCs, could be a good strategy for CVDs. Yoon et al. evaluated this combined cell therapy, demonstrating a synergistic neovascularization involving several cytokines and matrix metalloproteinases (MMPs) [77]. Very recently, our group has also corroborated the potential of CACs to promote angiogenesis of ECFCs in vitro, and such effect was impaired under an atherosclerotic environment [110]. In the same way, different cell combinations have been tested. Rossi et al. demonstrated that co-injection of MSCs with ECFCs in a murine model of CLI increased vessel density and foot perfusion in greater ratio than cells individually administrated; corroborating the theory that MSCs support ECFC-mediated angiogenic processes [72]. Furthermore, their results indicated that MSCs accelerated muscle recovery via endoglin dependent mechanism. Similarly, the combination of EPCs and smooth muscle progenitor cells (SMPCs) has also been evaluated to treat CLI. This cell mixture improved vascular network formation, with both ECs and smooth muscle cells (SMCs) participating in vessel maturation and stability. Likewise, Foubert et al. demonstrated that co-administration of EPCs and SMPCs activates neovascularization resulting in a more effective therapy than these cells administrated separately [78]. Some 
studies suggest that SMCs may also originate from bone marrow-derived cells as SMPCs have been identified in peripheral blood [111].

\subsection{Cell Therapies Based on Cellular Cocktails}

As an alternative to the injection of a single cell type or the combination of two previously isolated cells, the administration of cellular cocktails derived from different niches, such as bone marrow, peripheral blood, or adipose tissue, is also a frequent approach to treat CLI. Indeed, the regenerative properties of mononuclear cells (MNCs) derived from either bone marrow or peripheral blood have been largely studied in the last years. Therapies employing bone marrow mononuclear cells (BM-MNCs) constitute a promising alternative for CLI patients to avoid or delay the onset of amputation [112]. BM-MNCs consist of a heterogeneous mix of multipotent stem cells working cooperatively as MSCs, HSCs, EPCs, monocytes, lymphocytes, and pluripotent stem cells [41,113]. We and other researchers have reported the beneficial effects of different combinations of BM-MNCs, representing an effective approach in promoting new vessel formation, perfusion recovery, and CLI reversal [41,100,114-122]. In the ischemic tissue, BM-MNCs produce and secrete different cytokines and growth factors [123] and increase neovascularization and collateral vessel formation in limb ischemia [79]. Moreover, Kikuchi-Taura et al. have recently described that transplantation of BM-MNCs into a murine stroke model promoted ECs angiogenesis by gap junction mediated cell-cell interactions, elucidating a new theory of how cell-based therapies work, and suggesting that stem cells supply energy to injured cells [124]. This study suggested that, under hypoxic conditions, transplanted BM-MNCs are capable to transfer small molecules to ECs via gap junction interactions, leading to HIF-1 $\alpha$ activation, which induced upregulation of VEGF uptake into ECs and ECs autophagy suppression [124].

Alternatively to BM-MNCs, PB-MNCs are formed by circulating cells with angiogenic potential, thereby several studies involving the administration of these cells to treat CLI have also shown promising results $[125,126]$. Li et al. made a comparison between CD34+ and CD34- cells in PB-MNCs, concluding that both induce neovascularization, but only CD34+ incorporate into new capillaries [89]. PB-MNCs promote revascularization in ischemic limbs, even more when they are combined with platelet-rich plasma (PRP) [90]. PRP, a source of platelets, cytokines, and growth factors, participates in ECs proliferation and differentiation, interacting with important cell receptors related with angiogenesis [90]. Furthermore, in order to achieve high stem cell concentrations, hematopoietic growth factors are frequently used to induce cell mobilization. For example, prior PB-MNCs harvesting, progenitor cells are usually mobilized injecting granulocyte colony-stimulating factor (G-CSF) [125-128]. BM-MNCs and PB-MNCs treatments have been compared, and no significant differences have been observed between them [129,130]. Remarkably, without previous mobilization, PB-MNCs show higher concentration of mature cells as red blood cells, platelets, lymphocytes, and monocytes, while BM-MNCs show higher levels of EPCs [131].

The use of adipose tissue-derived stem cells (ASCs) has increased in the last years, due to the easier accessibility, abundance, and less painful collection compared to other sources such as bone marrow [132]. The stromal vascular fraction (SVF) derived from adipose tissue contains heterogeneous cell populations such as mesenchymal progenitor/stem cells, pre-adipocytes, endothelial cells, pericytes, T cells, and M2 macrophages. SVF-derived mesenchymal progenitor/stem cells, usually referred as ASCs themselves, can be easily expanded in vitro and have the potential to differentiate into multiple lineages, including myogenic, osteogenic, neurogenic, and hematopoietic pathways [133-137]. The angiogenic properties of these cells have been correlated with a strong paracrine activity, secreting an important number of angiogenesis-related cytokines [136]. Moreover, the administration of ASCs to CLI mice promotes a significant recovery of blood flow in ASCs treated mice compared to ischemic, non-treated ones [133]. Very recently, Liu J et al. have shown that the regenerative properties of transplanted ASCs might correlate with an immunomodulatory 
effect promoted by these cells. In presence of ASCs, a higher number of macrophages can be found in the muscle, with increased presence of M2 macrophages [91], and its administration in a murine model of CLI induces an angiogenic process in the ischemic tissue [133]. The clear advantages of using these cells are easy access and isolation. ASCs are highly abundant in adipose tissue, making almost unnecessary culture expansion of these cells. Moreover, adipose tissue harvesting requires a minimally invasive intervention [138]. A pilot study using adipose-derived regenerative cells (ADRCs) in CLI patients has been recently published [139].

Finally, other cells with multi-differentiation potential such as amniotic fluid derived stem cells (AFSCs) or umbilical cord blood and placenta tissue derived stem/progenitor cells have also been considered. Placenta-derived MSCs stromal-like cells (PLX-PAD) in CLI mice are currently being tested in a Phase III trial (PACE Trial) with atherosclerotic CLI patients (NCT03006770) after promising results in animal assays [95]. Unfortunately, the low availability of these cells together with ethics concerns related to their use, has limited their translation as cell therapies.

\section{Clinical Trials}

The exciting results derived from pre-clinical studies fomented the initiation of numerous clinical trials: to date, over 50 studies have investigated a variety of cell therapies, usually employing BM- or PB-derived MNCs, showing modest but significant improvements of ischemic symptoms [140,141]. Patients enrolling these trials normally suffered from severe stages of PAD (Fontaine III-IV) with pain at rest due to atherosclerosis obliterans (ASO) rather than thrombo-angiitis obliterans (TAO) or Buerger's Disease. The first clinical trial that reported the efficacy of autologous BM-MNCs administration as cell therapy for CLI was published in 2002 [142]. The Therapeutic Angiogenesis using Cell Transplantation (TACT) trial conducted a pilot study first with 25 patients, followed by a randomized controlled trial in which 22 patients with bilateral leg ischemia were injected with BM-MNCs in one leg and PB-MNCs in the other as controls. Their findings indicated a significant improvement in ankle-brachial index (ABI), transcutaneous oxygen pressure $\left(\mathrm{TcPO}_{2}\right)$, and pain-free walking time sustained at 24 weeks, with a limb status improved in 39 out of 45 patients [142]. Table 2 includes a list, far from complete, of clinical studies already completed and with results published in the past decades, involving the use of different cell types, cell doses, and administration routes, with a minimum of 10 patients enrolled. Due to the huge interest in the field, the number of ongoing clinical trials using cell therapy in CLI is constantly growing, including examples such as the Phase III PACE trial (PLX-PAD cells, NCT03006770) [143], or the Phase III trial testing Rexmyelocel-T (REX-001), a solution enriched with human BM-derived MNCs (NCT03174522 and NCT03111238) in CLI Rutherford V and DM patients. Some of these studies are active and recruiting, therefore, their results are not yet available. Additional information regarding such trials can be found at www.clinicaltrials.gov (accessed on 14 December 2020). 


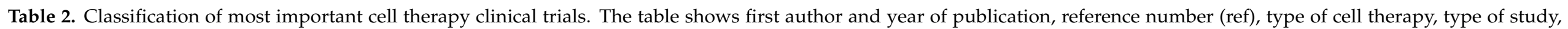

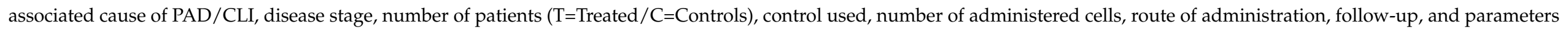

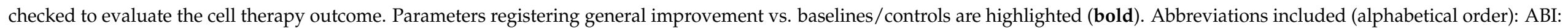

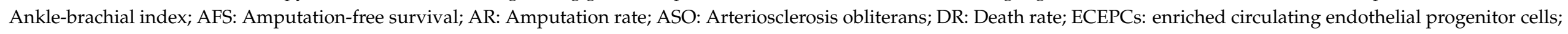

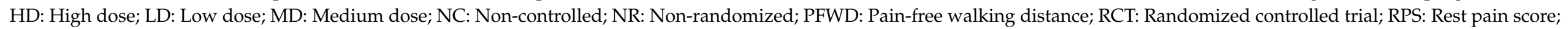
TAO: thromboangiitis obliterans; $\mathrm{TCPO}_{2}$ : Transcutaneous oxygen pressure; $\mathrm{UH}$ : Ulcer healing.

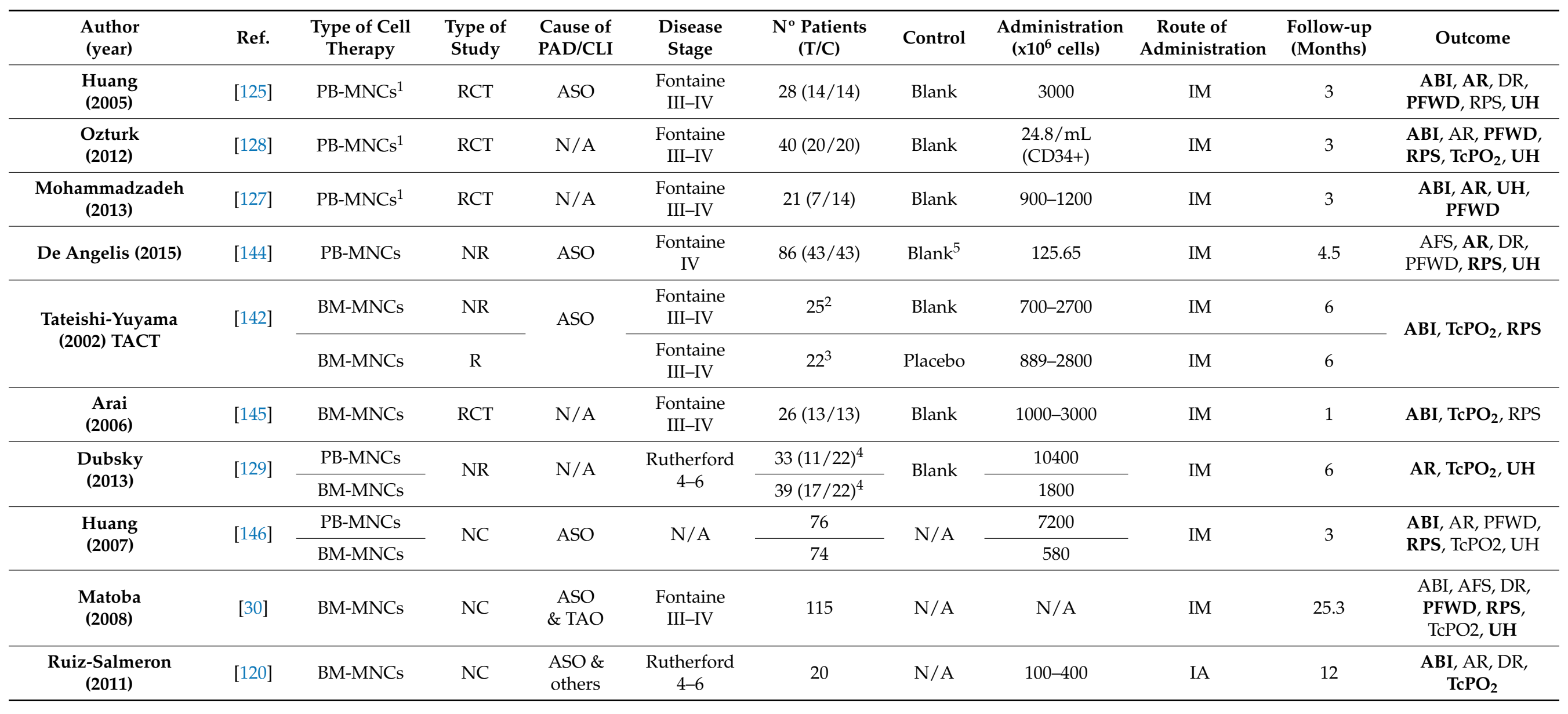


Table 2. Cont.

\begin{tabular}{|c|c|c|c|c|c|c|c|c|c|c|c|}
\hline $\begin{array}{c}\text { Author } \\
\text { (year) }\end{array}$ & Ref. & $\begin{array}{c}\text { Type of Cell } \\
\text { Therapy }\end{array}$ & $\begin{array}{l}\text { Type of } \\
\text { Study }\end{array}$ & $\begin{array}{l}\text { Cause of } \\
\text { PAD/CLI }\end{array}$ & $\begin{array}{c}\text { Disease } \\
\text { Stage }\end{array}$ & $\begin{array}{l}\mathrm{N}^{\circ} \text { Patients } \\
\text { (T/C) }\end{array}$ & Control & $\begin{array}{l}\text { Administration } \\
\left(\times 10^{6} \text { cells }\right)\end{array}$ & $\begin{array}{c}\text { Route of } \\
\text { Administration }\end{array}$ & $\begin{array}{l}\text { Follow-up } \\
\text { (Months) }\end{array}$ & Outcome \\
\hline \multirow{2}{*}{$\begin{array}{l}\text { Amann } \\
\text { (2009) BONMONT-1 }\end{array}$} & \multirow{2}{*}{ [114] } & BM-MNCs & \multirow{2}{*}{$\mathrm{NC}$} & \multirow{2}{*}{$\mathrm{N} / \mathrm{A}$} & \multirow{2}{*}{$\begin{array}{l}\text { Rutherford } \\
\quad 4-6\end{array}$} & 12 & \multirow{2}{*}{$\mathrm{N} / \mathrm{A}$} & 1100 & \multirow{2}{*}{$\mathrm{IM}$} & \multirow{2}{*}{13.5} & \multirow{2}{*}{$\begin{array}{l}\text { ABI, AFS, PFWD, } \\
\mathrm{TcPO}_{2}\end{array}$} \\
\hline & & BM-TNCs & & & & 39 & & 3000 & & & \\
\hline $\begin{array}{c}\text { Walter } \\
\text { (2011) PROVASA }\end{array}$ & {$[20]$} & BM-MNCs & $\mathrm{RCT}$ & $\begin{array}{c}\text { ASO } \\
\& \mathrm{TAO}\end{array}$ & $\begin{array}{l}\text { Fontaine } \\
\text { III-IV }\end{array}$ & $40(19 / 21)$ & Placebo & 153 & IA & 3 & $\begin{array}{c}\text { ABI, AR, DR, RPS, } \\
\text { TcPO }_{2}, \mathbf{U H}\end{array}$ \\
\hline $\begin{array}{c}\mathbf{L i} \\
(2013)\end{array}$ & [147] & BM-MNCs & $\mathrm{RCT}$ & ASO & $\begin{array}{l}\text { Fontaine } \\
\text { III-IV }\end{array}$ & $58(29 / 29)$ & Placebo & $10 / \mathrm{mL}$ & $\mathrm{IM}$ & 6 & $\begin{array}{c}\text { ABI, AFS, AR, DR, } \\
\text { RPS, UH }\end{array}$ \\
\hline $\begin{array}{c}\text { Teraa } \\
\text { (2015) JUVENTAS }\end{array}$ & [148] & BM-MNCs & $\mathrm{RCT}$ & ASO & $\begin{array}{l}\text { Fontaine } \\
\text { IIB-IV }\end{array}$ & $160(81 / 79)$ & Placebo & 500 & IA & 6 & $\begin{array}{l}\text { ABI, AR, DR, } \\
\text { TcPO }_{2}, \mathrm{UH}\end{array}$ \\
\hline Pignon (2017) BALI & [149] & BM-MNCs & RCT & ASO & $\begin{array}{l}\text { Rutherford } \\
\quad 4-5\end{array}$ & $36(17 / 19)$ & Placebo & 1300 & $\mathrm{IM}$ & 12 & $\begin{array}{c}\text { ABI, AR, RPS, } \\
\text { TcPO2, UH }\end{array}$ \\
\hline $\begin{array}{c}\text { Guo } \\
(2018)\end{array}$ & [116] & BM-MNCs & NR & TAO & $\mathrm{N} / \mathrm{A}$ & $59(40 / 19)$ & Blank & 3500 & $\mathrm{IM}$ & 129.5 & $\begin{array}{c}\text { ABI, AFS, AR, } \\
\text { RPS, TcPO } \\
\text {, UH }\end{array}$ \\
\hline $\begin{array}{c}\mathrm{Lu} \\
(2011)\end{array}$ & [150] & BM-MNCs & RCT & ASO & $\begin{array}{l}\text { Fontaine } \\
\text { IV }\end{array}$ & $21^{2}$ & Blank & 930 & $\mathrm{IM}$ & 6 & $\begin{array}{l}\text { ABI, AR, PFWT, } \\
\text { RPS, TcPO } 2, \text { UH }\end{array}$ \\
\hline \multirow{2}{*}{$\begin{array}{l}\text { Dash } \\
(2009)\end{array}$} & \multirow{2}{*}{ [151] } & \multirow{2}{*}{ BM-MSCs } & \multirow{2}{*}{$\mathrm{RCT}$} & ASO & \multirow{2}{*}{$\mathrm{N} / \mathrm{A}$} & $6(3 / 3)$ & \multirow{2}{*}{ Blank } & \multirow{2}{*}{$\mathrm{N} / \mathrm{A}$} & \multirow{2}{*}{$\mathrm{IM}$} & \multirow{2}{*}{3} & \multirow{2}{*}{ PFWD, UH } \\
\hline & & & & Buerger & & $18(9 / 9)$ & & & & & \\
\hline $\begin{array}{l}\text { Gupta } \\
(2013)\end{array}$ & [152] & $\begin{array}{l}\text { BM-MSCs } \\
\text { (allogenic) }\end{array}$ & $\mathrm{RCT}$ & $\begin{array}{c}\mathrm{ASO} \\
\& \mathrm{TAO}\end{array}$ & $\begin{array}{l}\text { Rutherford } \\
\quad 4-6\end{array}$ & $20(10 / 10)$ & Placebo & 200 & $\mathrm{IM}$ & 6 & ABI, AR, RPS, UH \\
\hline \multirow{2}{*}{$\begin{array}{l}\text { Szabò } \\
(2013)\end{array}$} & \multirow{2}{*}{ [153] } & \multirow{2}{*}{ Ves-Cell } & $\mathrm{RCT}$ & \multirow[t]{2}{*}{$\mathrm{N} / \mathrm{A}$} & \multirow{2}{*}{$\begin{array}{l}\text { Fontaine } \\
\text { III-IV }\end{array}$} & \multirow[t]{2}{*}{$20(10 / 10)$} & \multirow{2}{*}{ Blank } & 66.4 & IM & 3 & $\begin{array}{c}\text { ABI, AR, DR, } \\
\text { PFWD, RPS, } \\
\mathrm{TcPO}_{2}, \mathrm{UH}\end{array}$ \\
\hline & & & $\mathrm{NC}$ & & & & & & & 22.6 & $\begin{array}{c}\text { ABI, AFS, AR, } \\
\text { DR, PFWD, RPS, } \\
\text { TcPO }_{2}, \text { UH }\end{array}$ \\
\hline $\begin{array}{c}\text { Raval } \\
\text { (2014) SCRIPT-CLI }\end{array}$ & [154] & $\mathrm{CD} 133+{ }^{1}$ & $\mathrm{RCT}$ & ASO & $\mathrm{N} / \mathrm{A}$ & $10(3 / 7)$ & Placebo & $50-400$ & $\mathrm{IM}$ & 12 & AFS, AR, DR \\
\hline $\begin{array}{c}\text { Lara-Hernandez } \\
\text { (2010) }\end{array}$ & [155] & $\mathrm{EPCs}^{1}$ & $\mathrm{NC}$ & $\begin{array}{c}\text { ASO } \\
\& \mathrm{TAO}\end{array}$ & $\begin{array}{l}\text { Fontaine } \\
\text { III-IV }\end{array}$ & 28 & $\mathrm{~N} / \mathrm{A}$ & $\mathrm{N} / \mathrm{A}$ & $\mathrm{IM}$ & 14.7 & ABI, RPS, UH \\
\hline
\end{tabular}


Table 2. Cont.

\begin{tabular}{|c|c|c|c|c|c|c|c|c|c|c|c|}
\hline $\begin{array}{l}\text { Author } \\
\text { (year) }\end{array}$ & Ref. & $\begin{array}{l}\text { Type of Cell } \\
\text { Therapy }\end{array}$ & $\begin{array}{l}\text { Type of } \\
\text { Study }\end{array}$ & $\begin{array}{l}\text { Cause of } \\
\text { PAD/CLI }\end{array}$ & $\begin{array}{l}\text { Disease } \\
\text { Stage }\end{array}$ & $\begin{array}{l}N^{\circ} \text { Patients } \\
\text { (T/C) }\end{array}$ & Control & $\begin{array}{l}\text { Administration } \\
\left(\times 10^{6} \text { cells }\right)\end{array}$ & $\begin{array}{c}\text { Route of } \\
\text { Administration }\end{array}$ & $\begin{array}{l}\text { Follow-up } \\
\text { (Months) }\end{array}$ & Outcome \\
\hline $\begin{array}{l}\text { Kinoshita } \\
\text { (2012) }\end{array}$ & [156] & $\mathrm{CD} 34+^{1}$ & $\mathrm{NC}$ & $\begin{array}{l}\text { ASO \& } \\
\text { Buerger }\end{array}$ & $\begin{array}{l}\text { Rutherford } \\
\quad 4-5\end{array}$ & 17 & $\mathrm{~N} / \mathrm{A}$ & $\begin{array}{c}0.1 / \mathrm{kg}(\mathrm{LD}) \\
0.5 / \mathrm{kg}(\mathrm{MD}) \\
1 / \mathrm{kg}(\mathrm{HD})\end{array}$ & $\mathrm{IM}$ & 12 & $\begin{array}{l}\text { AR, DR, PFWD, } \\
\text { RPS, TcPO }{ }_{2}, \mathrm{UH}\end{array}$ \\
\hline $\begin{array}{l}\text { Dong } \\
(2013)\end{array}$ & [157] & $\mathrm{CD} 34+^{1}$ & $\mathrm{NC}$ & $\begin{array}{c}\text { ASO, } \\
\text { TAO } \\
\text { \& others }\end{array}$ & $\begin{array}{l}\text { Rutherford } \\
\quad 4-5\end{array}$ & 25 & $\mathrm{~N} / \mathrm{A}$ & $\begin{array}{c}0.1 / \mathrm{kg}(\mathrm{LD}) \\
0.5 / \mathrm{kg}(\mathrm{MD}) \\
1 / \mathrm{kg}(\mathrm{HD})\end{array}$ & IM & 6 & $\begin{array}{c}\text { ABI, AR, DR, } \\
\text { PFWT, RPS, } \\
\mathrm{TcPO}_{2}, \mathrm{UH}\end{array}$ \\
\hline $\begin{array}{c}\text { Powell } \\
\text { (2012) RESTORE-CLI }\end{array}$ & [159] & Ixmyelocel-T & $\mathrm{RCT}$ & $\mathrm{N} / \mathrm{A}$ & $\mathrm{N} / \mathrm{A}$ & $72(48 / 24)$ & Placebo & 35-295 & IM & 12 & AFS, AR, DR \\
\hline $\begin{array}{l}\text { Losordo } \\
\text { (2015) }\end{array}$ & [160] & $\mathrm{CD} 34+{ }^{1}$ & $\mathrm{RCT}$ & $\mathrm{N} / \mathrm{A}$ & $\begin{array}{l}\text { Rutherford } \\
\quad 4-5\end{array}$ & $28(16 / 12)$ & Placebo & $\begin{array}{l}0.1 / \mathrm{kg}(\mathrm{LD}) \\
1 / \mathrm{kg}(\mathrm{HD})\end{array}$ & IM & 12 & $\begin{array}{l}\text { ABI, AR, DR, } \\
\text { PFWD, UH }\end{array}$ \\
\hline \multirow{2}{*}{ Liotta (2018) } & \multirow{2}{*}{ [161] } & BM-MNCs & \multirow{2}{*}{$\mathrm{R}$} & \multirow{2}{*}{$\mathrm{N} / \mathrm{A}$} & \multirow{2}{*}{$\begin{array}{l}\text { Rutherford } \\
\quad 4-6\end{array}$} & 17 & \multirow{2}{*}{ Blank $^{5}$} & $50^{6}$ & \multirow{2}{*}{ IM } & \multirow{2}{*}{12} & \multirow{2}{*}{$\begin{array}{l}\text { ABI, PFWD, RPS, } \\
\text { TcPO2, UH }\end{array}$} \\
\hline & & ECEPCs & & & & 23 & & $250^{6}$ & & & \\
\hline Fang (2020) & [162] & $\mathrm{CD} 34+{ }^{1}$ & $\mathrm{RCT}$ & TAO & $\begin{array}{l}\text { Rutherford } \\
\quad 4-5\end{array}$ & 82 & PB-MNC & $31,95^{7}$ & IM & 46,6 & $\begin{array}{c}\text { ABI, AFS, PFWT, } \\
\text { RPS, TcPO2 }\end{array}$ \\
\hline Sharma (2021) & [163] & BM-MNCs & $\mathrm{RCT}$ & $\begin{array}{l}\text { ASO \& } \\
\text { others }\end{array}$ & $\begin{array}{l}\text { Fontaine } \\
\text { IIC-IV }\end{array}$ & $81(41 / 40)$ & Placebo & 71,51 & IA & 6 & $\begin{array}{l}\text { ABI, AR, PFWD, } \\
\text { RPS, TcPO2, UH }\end{array}$ \\
\hline
\end{tabular}

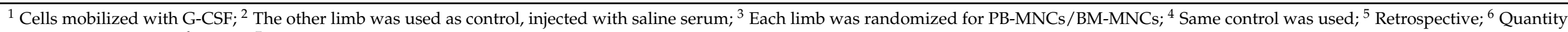
referred to CD14+CD34 ${ }^{\text {low }}$ cells; ${ }^{7}$ Quantity referred to CD34+ cells. 
One of the primary outcomes seen in clinical trials is hemodynamic improvement, represented as an absolute increase of $\mathrm{ABI}>10 \%[12,164]$. Similarly, other researchers have reported an enhanced blood perfusion when administering either BM-MNCs, PB-MNCs, or MSCs $[114,125,127,128,145,147,150,153]$. Gupta et al. evaluated the effect of allogenic MSCs in patients (Rutherford grade 4-6) that suffered from CLI due to ASO and TAO. This study reported a significant increase of ABI $(p=0.0018)$ after 6 months of MSCs treatment (n:10) compared to patients transplanted with placebo (n:10), although no such significant changes could be observed in rest pain, ulcer healing, or amputation rates. Some authors debate about the selection of ABI as a primary endpoint, as this parameter is not considered a useful predictor for evaluating the long-term efficiency of the angiogenic therapy using bone marrow cells $[20,142]$. The PROVASA study, a randomized, double-blind, placebocontrolled intra-arterial progenitor cell transplantation of BM-MNCs for induction of neovascularization in patients with PAD, showed no significant differences in ABI primary outcome at 3 months. However, authors did observe significant improvements in other secondary endpoints, like ulcer healing and rest pain reduction in the BM-MSCs group [20].

Luckily, cell therapy has promoted an amelioration of the symptoms and therefore an improvement in the quality-of-life of these patients $[158,160]$. Thus, an improvement in rest pain is defined as a $>50 \%$ decrease in pain scores, assessed with the visual analogue scale (VAS) at different time points [165]. In a non-randomized study, CLI-TAO patients (n:40) received autologous BM-MNCs, and after a mean follow-up of 129 months, a prominent improvement in VAS $(p=0.0001)$ was seen, also in their primary endpoint amputation-free survival and other secondary outcomes including ulcer status, ABI, toe-brachial index, and $\mathrm{TcPO}_{2}$ [116]. This last hemodynamic measurement is employed in several clinical trials as secondary endpoint, and an augmentation in oxygen pressure has been observed in numerous studies using PB-MNCs, BM-MNCs, MSCs, as well as peripheral blood-derived angiogenic cell precursors (Ves-cells) [20,114,116,128,129,142,145,150,153].

Alternatively, CD34+ or CD133+ isolated cells have also been tested in CLI studies. In a randomized single-blinded non-inferiority trial, patients were divided 1:1 into those receiving either PB-MNCs or purified CD34+ cells. Although the number of patients included in this study was low, similar results were found in terms of limb salvage and quality of life improvements. No significant differences were found between both treatments in terms of amputation-free survival. On the other hand, the CD34+ group seemed to achieve faster rest-pain relief and overall earlier ischemia relief than the PB-MNCs group [166]. In the Stem Cell Revascularization for Patients with Critical Limb Ischemia (SCRIPT-CLI) trial, subjects with CLI due to ASO were divided in two groups in 2:1 proportion, receiving an active treatment with G-CSF for 5 days before leukapheresis and CD133+ injection in both legs, and a group receiving saline injections plus a sham leukapheresis and a placebobuffered solution instead of cells. The safety of the procedure was proven 12 months after treatment, whereas a poor mobilization of CD133+ cells was found in several patients, together with higher rates of CD133+ senescent cells. These results reflected the need of studies with higher number of patients. Nevertheless, these authors suggested that this therapeutic approach might not be entirely successful with the patients selected [154]. Finally, other type of cells gaining popularity as a potential treatment for CLI patients are ASCs, SVF, or the very small embryonic-like stem cells (VSEL) $[139,167,168]$.

\section{Limitations in Cell-based Clinical Trials}

Despite the promising results derived from the use of stem cells with CLI patients, the variability and heterogeneity found within the clinical trials is high. Remarkably, after 20 years of using stem cell therapy in CLI, it remains unclear which cell type or cell source triggers the highest benefits in terms of blood perfusion recovery or amelioration of ischemic symptoms. The first trials focused on using heterogeneous cell preparations from either bone marrow of peripheral blood. Such unpurified cell mixtures are often composed by a considerably low proportion of "active" cells, or cells with documented pro-angiogenic functions $[109,125,142,169]$. On the other hand, large amounts of cells are 
required during cell therapy, but proangiogenic progenitor cells are not present in high proportions in humans, being necessary to develop optimized and clinically applicable culture expansion methods for future perspectives. Cells could be efficiently selected by their expression of CD34, CD133, or also by their ALDH-activity, although this approach have detractors too, as extended culture is thought to negatively affect cell regenerative function $[170,171]$. However, the optimization of these cultures could solve the problematic associated with EPCs or MSCs dysfunctionality in CLI patients, as well as augmenting the angiogenic potency of cells through pre-stimulation prior transplantation $[47,172]$. In this sense, the next question relies in whether using an autologous or an allogenic strategy with these patients. Autologous administration avoids rejection-related issues, but also presents several disadvantages such as difficulties to recruit a significant number of cells from these donors, and moreover the already mentioned cellular dysfunction in response to atherosclerosis and/or related co-morbidities. The allogenic method complicates the therapy applicability by requiring HLA-matching [173-175].

Another matter of disparity is the cell dose to apply, depending on the cell type/source, as the number of MNCs and purified cells from MNCs always vary between patients and could be affected by the illness itself. Unfortunately, some studies did not even provide such information $[30,170,174]$. Similarly, the route of administration has not reached a consensus yet. The majority of trials have chosen an intramuscular cell delivery, considering this a more feasible and less invasive strategy $[147,150]$. Other authors postulate that an intraarterial administration would better distribute the cells into areas with sufficient oxygen to prolong the pro-angiogenic function, trying to avoid the transient cell engraftment and integration after intramuscular injection $[20,87,148]$. In this regard, several studies have compared both intramuscular and intra-arterial strategies, showing similar results in terms of clinical outcome [176-178].

Overall, the comparison of the results derived from different trials comprises an arduous task in which meta-analysis are becoming increasingly useful to support evidencebased medicine, allowing to summarize the accumulated evidence and also to drive future research [179]. A meta-analysis performed by Rigato et al. includes robust statistical analysis of either randomized, controlled trials, and non-controlled studies. Their results showed that in patients not eligible for surgical revascularization, autologous cell therapy has the potential to reduce the risk of major amputation in $36 \%$, improving also the probability of wound healing in 59\%. Moreover, it appears to ameliorate several surrogate endpoints of limb perfusion, pain, and functional capacity [180]. Similarly, Gao et al. analyzed the results of over a thousand patients enrolling randomized controlled trials, indicating that cell implantation improved ulcer healing rate, $\mathrm{ABI}, \mathrm{TcPO}_{2}$, pain-free walking distance, and reduced amputation rate and rest pain score compared with standard care/conventional treatment [181]. Very recently, a review including 11 meta-analyses evaluated current evidence on cell-based therapy in PAD. Such study corroborates the effectiveness of using cell therapy with CLI patients, with a reduction in the number of major amputations and improved wound healing. Furthermore, for secondary outcomes such as $\mathrm{ABI}, \mathrm{TcPO}_{2}$, and RPS, a general improvement is seen [179]. Despite this, larger studies are required to increase statistical significance, together with the design of placebo-controlled studies, as clinical outcome differences are not clear when compared to the placebo effect [181,182].

The discrepancy found between the clinical trials reflects the fact that there is still a lot of work to do, as stated before, in order to reach a consensus regarding the optimal treatment. This, in turn, also requires of a better understanding of how cells work, in order to implement their use in clinical practice. Still, these studies share a common conclusion: the safety and feasibility of cell therapy in patients with no option of surgical revascularization, a population that represents half of the CLI patients diagnosed $[120,144]$.

\section{Strategies Derived from Cell Therapy}

Due to increasing number of studies supporting that the regenerative power of stem cells is mainly due to their paracrine effect within the ischemic tissues, the use of the cells 
released factors (secretome) and, more recently, the so-called exosomes as an alternative to cell therapy, is currently being investigated. Secretomes are also named in different studies as conditioned medium (CM), referring to the factors released to the medium where cells have been cultured. The modulatory effect of these secretomes could depend on the presence of different growth factors, angiogenic factors, hormones, cytokines, extracellular matrix proteins and proteases, hormones, lipid mediators and genetic material secreted from stem or progenitor cells for cell communications, interfering in different biological functions such as growth, division, differentiation, apoptosis, and signaling [183,184]. The stem cell secretome has shown great potential and could mediate intracellular pathways in injured cells or activate adjacent tissues secretion [184].

Secretomes derived from different progenitor or stem cells are being studied, especially thanks to mass spectrometry approaches. In this way, Barberg et al. analyzed the MSCs secretome composition, identifying proteins related to cell growth, signal transduction and cell communication, as well as cytokines and growth factors involved in physiological regulation of hematopoiesis [185]. Likewise, Maffioli et al. described that, in a proinflammatory environment, MSCs increase the secretion of proteins related with immunomodulation and angiogenesis [186]. Although MSCs secretomes are the most studied ones, secretomes of other stem/progenitor cells are also showing promising results. Very recently, we analyzed by a proteomic approach the secretome of CACs, identifying a significant number of angiogenic factors, and moreover, we demonstrated that incubation ex vivo of ECFCs with this secretome enhances ECFCs angiogenesis, in agreement with previous studies $[77,110]$. Moreover, ASCs secretome contains multiple angiogenic factors, which appear to promote, among others, survival, proliferation, and migration of ECs, as well as vasculogenesis $[187,188]$. Indeed, ASCs conditioned medium has been shown to enhance proliferation and survival of endothelial cells in vitro [133]. Some of these secretomes have already been tested as therapy in vivo showing encouraging results, since they seem to be as effective as cell therapy [189-191]. The complete knowledge of the secretomes activity and their factors would allow us to reproduce them artificially by means of bioactive molecules to use in regenerative medicine. Finally, the administration of secretomes as an alternative approach to cell therapy eliminates disadvantages such as immune rejection or tumorigenicity [184]. Currently, novel strategies such as secretomes liberation approaches to enhance their angiogenic properties are being evaluated. For example, Felice et al. used nanoparticles to achieve a controlled EPCs secretome, demonstrating the potential of this system in FAL rat models [192]. Likewise, extracellular vesicles derived from stem or progenitor cells, also called "exosomes", seem to participate as well in the regenerative role of cellular secretomes. Exosomes derived from MSCs appear to promote bone regeneration and angiogenesis [193]. In the same way, exosomes derived from CD34+ cells have been shown to participate in angiogenesis and are essential for the repairing properties assigned to these cells [194].

Finally, microRNAs have recently arisen as a promising alternative therapy against ischemic diseases. MicroRNAs, short non-coding RNAs that inhibit translation of messenger RNAs, can regulate an entire network or pathway simultaneously, besides, in response to ischemia, they appear to be involved in the regulation of angiogenesis and arteriogenesis $[58,195]$. Different strategies against PAD are based on the modulation of factors related to the development of vasculature. However, modifications in a single factor do not seem to be sufficient for the treatment of this disease, and therefore the development of therapeutic strategies based on microRNAs are very promising, as this approach would allow to regulate several pathways at the same time. Some of the most studied microRNAs in CLI are miR-494, miR-487b, miR-329, and miR-495. Thus, the inhibition of some of these molecules, described as antiangiogenic microRNAs, seems to promote blood flow recovery in CLI mice $[195,196]$. Some studies suggest that microRNAs could be transferred by stem or progenitor cells through exosomes to ECs, promoting angiogenesis in these forms [197]. Although microRNAs are the best known and most studied RNA non-coding molecules for their therapeutic potential, there are other related types of RNA, such as circular or long 
noncoding RNAs, that also act in the regulation of gene expression and therefore should be also evaluated as therapeutic targets.

\section{Conclusions}

In the past decades, an enormous effort has been made to find appropriate strategies for the optimal treatment of CLI patients. Stem cell-based therapies have proven to be safe and efficient to achieve therapeutic angiogenesis and to promote blood flow recovery, representing an alternative for these patients. In this sense, the interest in the field is clear, and the number of clinical trials using cell therapy in CLI is constantly growing. Still, the variability seen between these trials is high, reflecting a lack of consensus regarding key factors such as cell doses, cell types or sources, administration routes, the parameters to define outcome efficacy, or the cohorts themselves. Moreover, further investigation is required in order to better understand how the cells, or the molecules/exosomes derived from them, exert such beneficial effects. Thus, a lot of work needs to be done before their translation into the clinical practice. Even so, the results are promising, and a therapy based on the administration of stem/progenitor cells and/or their derivatives could hopefully represent a good alternative for CLI patients, especially for those with no other options.

Author Contributions: Conceptualization: L.B.-C., M.R.-T., and M.C.D.-R.; data curation: L.B.-C., M.R.-T., and M.C.D.-R.; writing - original draft preparation: L.B.-C., M.R.-T., and M.C.D.-R.; writingreview and editing: L.B.-C., M.R.-T., and M.C.D.-R.; supervision, project administration, and funding acquisition: M.C.D.-R. All authors have read and agreed to the published version of the manuscript.

Funding: This work was supported by the Institute of Health Carlos III, ISCIII (PI16-00784, PI2000716) and the Programa Operativo de Andalucia FEDER, Iniciativa Territorial Integrada ITI 20142020 Consejeria de Salud, Junta de Andalucia (PI0026-2017).

Institutional Review Board Statement: Not applicable.

Informed Consent Statement: Not applicable.

Data Availability Statement: Not applicable.

Conflicts of Interest: The authors declare no conflict of interest.

\begin{tabular}{ll}
\multicolumn{2}{l}{ Abbreviations } \\
a & Autologous \\
ABI & Ankle brachial index \\
aBMCs & Autologous bone marrow cell transplantation \\
AD & Arteriolar density \\
ADRCs & Adipose-derived regenerative cells \\
AFS & Amputation free survival \\
AFSCs & Amniotic fluid-derived stem cells \\
AI & Angiographic index \\
AR & Amputation rate \\
ASCs & Adipose tissue derived stem cells \\
ASO & Atherosclerosis obliterans \\
BM-MNCs & Bone marrow-derived mononuclear cells \\
BM-MSCs & Bone marrow mesenchymal stem cells \\
BM-TNCs & Bone marrow total nucleated cells \\
BFP & Blood flow perfusion \\
CACs & Circulating angiogenic cells \\
CBF & Calf blood pressure \\
CD & Capillary density
\end{tabular}




\begin{tabular}{|c|c|}
\hline $\mathrm{CM}$ & Conditioned medium \\
\hline CLI & Critical limb ischemia \\
\hline CVDs & Cardiovascular diseases \\
\hline CVF & Collateral vessel formation \\
\hline $\mathrm{DM}$ & Diabetes mellitus \\
\hline DR & Death rate \\
\hline ECFCs & Endothelial colony forming cells \\
\hline ECs & Endothelial cells \\
\hline ECEPCs & Enriched circulating endothelial progenitor cells \\
\hline EPCs & Endothelial progenitor cells \\
\hline ESC-ECP & Stem cell-derived endothelial cell product \\
\hline FAL & Femoral artery ligation \\
\hline FGF1 & Fibroblast growth factor 1 \\
\hline FS & Functional score \\
\hline G-CSF & Granulocyte colony-stimulating factor \\
\hline HD & High dose \\
\hline HGF & Hepatocyte growth factor \\
\hline HIF-1a & Hypoxia-inducible factor 1-alpha \\
\hline HPCs & Hematopoietic progenitor cells \\
\hline $\mathrm{h}$ & Human \\
\hline IA & Intraarterial \\
\hline IC & Intracardiac \\
\hline $\mathrm{IHC}$ & Immunohistochemistry \\
\hline $\mathrm{IM}$ & Intramuscular \\
\hline IV & Intravenous \\
\hline LD & Low dose \\
\hline LDP & Laser Doppler Perfusion \\
\hline MACs & Myeloid angioenic cells \\
\hline MD & Medium dose \\
\hline MMPs & Matrix metalloproteinases \\
\hline MP & Matrigel plug \\
\hline MSCs & Mesenchymal stem cells \\
\hline NC & Non-controlled \\
\hline $\mathrm{NO}$ & Nitric oxide \\
\hline NR & Non-randomized \\
\hline PAD & Peripheral arterial disease \\
\hline PB-MNCs & Peripheral blood mononuclear cells \\
\hline PFWD & Pain-free walking distance \\
\hline PRP & Platelet-rich plasma \\
\hline RCT & Randomized controlled trial \\
\hline RPS & Rest pain score \\
\hline SC & Subcutaneous \\
\hline SMCs & Smooth muscle cells \\
\hline SMPCs & Smooth muscle progenitor cells \\
\hline SVF & Stromal vascular fraction \\
\hline TAO & Thrombo-angiitis obliterans \\
\hline $\mathrm{TcPO}_{2}$ & Transcutaneous oxygen pressure \\
\hline TR & Tissue regeneration \\
\hline UH & Ulcer healing \\
\hline VAS & Visual analogue scale \\
\hline VD & Vessel diameter \\
\hline VEGF & Vascular endothelial growth factor \\
\hline VIP & Vascular intersection percentage \\
\hline VS & Visual Scale \\
\hline VSEL & Very small embryonic-like stem cells \\
\hline
\end{tabular}




\section{References}

1. Conte, S.M.; Vale, P.R. Peripheral Arterial Disease. Heart Lung Circ. 2018, 27, 427-432. [CrossRef] [PubMed]

2. Balakumar, P.; Maung, U.K.; Jagadeesh, G. Prevalence and prevention of cardiovascular disease and diabetes mellitus. Pharmacol. Res. 2016, 113 Pt A, 600-609. [CrossRef] [PubMed]

3. van Weel, V.; van Tongeren, R.B.; van Hinsbergh, V.W.; van Bockel, J.H.; Quax, P.H. Vascular growth in ischemic limbs: A review of mechanisms and possible therapeutic stimulation. Ann. Vasc. Surg. 2008, 22, 582-597. [CrossRef]

4. Krishna, S.M.; Moxon, J.V.; Golledge, J. A review of the pathophysiology and potential biomarkers for peripheral artery disease. Int. J. Mol. Sci. 2015, 16, 11294-11322. [CrossRef]

5. Giacco, F.; Brownlee, M. Oxidative stress and diabetic complications. Circ. Res. 2010, 107, 1058-1070. [CrossRef]

6. Hao, C.; Shintani, S.; Shimizu, Y.; Kondo, K.; Ishii, M.; Wu, H.; Murohara, T. Therapeutic angiogenesis by autologous adiposederived regenerative cells: Comparison with bone marrow mononuclear cells. Am. J. Physiol. Heart Circ. Physiol. 2014, 307, H869-H879. [CrossRef]

7. Jude, E.B.; Oyibo, S.O.; Chalmers, N.; Boulton, A.J. Peripheral arterial disease in diabetic and nondiabetic patients: A comparison of severity and outcome. Diabetes Care 2001, 24, 1433-1437. [CrossRef] [PubMed]

8. Pickup, J.C.; Chusney, G.D.; Thomas, S.M.; Burt, D. Plasma interleukin-6, tumour necrosis factor alpha and blood cytokine production in type 2 diabetes. Life Sci. 2000, 67, 291-300. [CrossRef]

9. Nehler, M.R.; Duval, S.; Diao, L.; Annex, B.H.; Hiatt, W.R.; Rogers, K.; Zakharyan, A.; Hirsch, A.T. Epidemiology of peripheral arterial disease and critical limb ischemia in an insured national population. J. Vasc. Surg. 2014, 60, 686-695 e2. [CrossRef]

10. Suggested standards for reports dealing with lower extremity ischemia. Prepared by the Ad Hoc Committee on Reporting Standards, Society for Vascular Surgery/North American Chapter, International Society for Cardiovascular Surgery. J. Vasc. Surg. 1986, 4, 80-94.

11. Fontaine, R.; Kim, M.; Kieny, R. [Surgical treatment of peripheral circulation disorders]. Helv. Chir. Acta. 1954, $21,499-533$.

12. Rutherford, R.B.; Baker, J.D.; Ernst, C.; Johnston, K.W.; Porter, J.M.; Ahn, S.; Jones, D.N. Recommended standards for reports dealing with lower extremity ischemia: Revised version. J. Vasc. Surg. 1997, 26, 517-538. [CrossRef]

13. Becker, F.; Robert-Ebadi, H.; Ricco, J.B.; Setacci, C.; Cao, P.; de Donato, G.; Eckstein, H.H.; De Rango, P.; Diehm, N.; Schmidli, J.; et al. Chapter I: Definitions, epidemiology, clinical presentation and prognosis. Eur. J. Vasc. Endovasc. Surg. 2011, 42 (Suppl. 2), S4-S12. [CrossRef]

14. Dormandy, J.A.; Rutherford, R.B. Management of peripheral arterial disease (PAD). TASC Working Group. TransAtlantic Inter-Society Consensus (TASC). J. Vasc. Surg. 2000, 31 Pt 2, S1-S296. [PubMed]

15. Norgren, L.; Hiatt, W.R.; Dormandy, J.A.; Nehler, M.R.; Harris, K.A.; Fowkes, F.G.; Group, T.I.W. Inter-Society Consensus for the Management of Peripheral Arterial Disease (TASC II). J. Vasc. Surg. 2007, 45 (Suppl. S), S5-S67. [CrossRef] [PubMed]

16. Teraa, M.; Conte, M.S.; Moll, F.L.; Verhaar, M.C. Critical Limb Ischemia: Current Trends and Future Directions. J. Am. Heart Assoc. 2016, 5, e002938. [CrossRef] [PubMed]

17. Conte, M.S.; Pomposelli, F.B. Society for Vascular Surgery Practice guidelines for atherosclerotic occlusive disease of the lower extremities management of asymptomatic disease and claudication. Introduction. J. Vasc. Surg. 2015, 61 (Suppl. 3), 1S. [CrossRef]

18. Hirsch, A.T.; Haskal, Z.J.; Hertzer, N.R.; Bakal, C.W.; Creager, M.A.; Halperin, J.L.; Hiratzka, L.F.; Murphy, W.R.; Olin, J.W.; Puschett, J.B.; et al. ACC/AHA 2005 Practice Guidelines for the management of patients with peripheral arterial disease (lower extremity, renal, mesenteric, and abdominal aortic): A collaborative report from the American Association for Vascular Surgery/Society for Vascular Surgery, Society for Cardiovascular Angiography and Interventions, Society for Vascular Medicine and Biology, Society of Interventional Radiology, and the ACC/AHA Task Force on Practice Guidelines (Writing Committee to Develop Guidelines for the Management of Patients With Peripheral Arterial Disease): Endorsed by the American Association of Cardiovascular and Pulmonary Rehabilitation; National Heart, Lung, and Blood Institute; Society for Vascular Nursing; TransAtlantic Inter-Society Consensus; and Vascular Disease Foundation. Circulation 2006, 113, e463-e654.

19. Simpson, E.L.; Kearns, B.; Stevenson, M.D.; Cantrell, A.J.; Littlewood, C.; Michaels, J.A. Enhancements to angioplasty for peripheral arterial occlusive disease: Systematic review, cost-effectiveness assessment and expected value of information analysis. Health Technol. Assess. 2014, 18, 1-252. [CrossRef]

20. Walter, D.H.; Krankenberg, H.; Balzer, J.O.; Kalka, C.; Baumgartner, I.; Schluter, M.; Tonn, T.; Seeger, F.; Dimmeler, S.; Lindhoff-Last, E.; et al. Intraarterial administration of bone marrow mononuclear cells in patients with critical limb ischemia: A randomized-start, placebo-controlled pilot trial (PROVASA). Circ. Cardiovasc. Interv. 2011, 4, 26-37. [CrossRef]

21. Lawall, H.; Zemmrich, C.; Bramlage, P.; Amann, B. Health related quality of life in patients with critical limb ischemia. Vasa 2012, 41, 78-88. [CrossRef]

22. Patel, R.S. Team Approach to Critical Limb Ischemia Care and Research. Tech. Vasc Interv. Radiol. 2016, 19, 101-103. [CrossRef]

23. Setacci, C.; de Donato, G.; Teraa, M.; Moll, F.L.; Ricco, J.B.; Becker, F.; Robert-Ebadi, H.; Cao, P.; Eckstein, H.H.; De Rango, P.; et al. Chapter IV: Treatment of critical limb ischaemia. Eur. J. Vasc. Endovasc. Surg. 2011, 42 (Suppl. 2), S43-S59. [CrossRef]

24. Lichtenberg, M.; Schreve, M.A.; Ferraresi, R.; van den Heuvel, D.A.F.; Unlu, C.; Cabane, V.; Kum, S. Surgical and endovascular venous arterialization for treatment of critical limb ischaemia. Vasa 2018, 47, 17-22. [CrossRef]

25. Duff, S.; Mafilios, M.S.; Bhounsule, P.; Hasegawa, J.T. The burden of critical limb ischemia: A review of recent literature. Vasc Health Risk Manag. 2019, 15, 187-208. [CrossRef] [PubMed] 
26. Spreen, M.I.; Gremmels, H.; Teraa, M.; Sprengers, R.W.; Verhaar, M.C.; Statius van Eps, R.G.; de Vries, J.P.; Mali, W.P.; van Overhagen, H.; Padi; et al. Diabetes Is Associated with Decreased Limb Survival in Patients With Critical Limb Ischemia: Pooled Data From Two Randomized Controlled Trials. Diabetes Care 2016, 39, 2058-2064. [CrossRef]

27. Howangyin, K.Y.; Silvestre, J.S. Diabetes mellitus and ischemic diseases: Molecular mechanisms of vascular repair dysfunction. Arterioscler. Thromb. Vasc. Biol. 2014, 34, 1126-1135. [CrossRef] [PubMed]

28. Ouma, G.O.; Zafrir, B.; Mohler, E.R., 3rd; Flugelman, M.Y. Therapeutic angiogenesis in critical limb ischemia. Angiology 2013, 64, 466-480. [CrossRef] [PubMed]

29. Belch, J.; Hiatt, W.R.; Baumgartner, I.; Driver, I.V.; Nikol, S.; Norgren, L.; Van Belle, E.; TAMRIS Committees and Investigators. Effect of fibroblast growth factor NV1FGF on amputation and death: A randomised placebo-controlled trial of gene therapy in critical limb ischaemia. Lancet 2011, 377, 1929-1937. [CrossRef]

30. Matoba, S.; Tatsumi, T.; Murohara, T.; Imaizumi, T.; Katsuda, Y.; Ito, M.; Saito, Y.; Uemura, S.; Suzuki, H.; Fukumoto, S.; et al. Long-term clinical outcome after intramuscular implantation of bone marrow mononuclear cells (Therapeutic Angiogenesis by Cell Transplantation [TACT] trial) in patients with chronic limb ischemia. Am. Heart J. 2008, 156, 1010-1018. [CrossRef] [PubMed]

31. Powell, R.J.; Goodney, P.; Mendelsohn, F.O.; Moen, E.K.; Annex, B.H.; Investigators, H.G.F.T. Safety and efficacy of patient specific intramuscular injection of HGF plasmid gene therapy on limb perfusion and wound healing in patients with ischemic lower extremity ulceration: Results of the HGF-0205 trial. J. Vasc. Surg. 2010, 52, 1525-1530. [CrossRef]

32. van Royen, N.; Schirmer, S.H.; Atasever, B.; Behrens, C.Y.; Ubbink, D.; Buschmann, E.E.; Voskuil, M.; Bot, P.; Hoefer, I.; Schlingemann, R.O.; et al. START Trial: A pilot study on STimulation of ARTeriogenesis using subcutaneous application of granulocyte-macrophage colony-stimulating factor as a new treatment for peripheral vascular disease. Circulation 2005, 112, 1040-1046. [CrossRef] [PubMed]

33. Ko, S.H.; Bandyk, D.F. Therapeutic angiogenesis for critical limb ischemia. Semin. Vasc. Surg. 2014, 27, 23-31. [CrossRef]

34. Lee, C.W.; Stabile, E.; Kinnaird, T.; Shou, M.; Devaney, J.M.; Epstein, S.E.; Burnett, M.S. Temporal patterns of gene expression after acute hindlimb ischemia in mice: Insights into the genomic program for collateral vessel development. J. Am. Coll. Cardiol. 2004, 43, 474-482. [CrossRef]

35. Westvik, T.S.; Fitzgerald, T.N.; Muto, A.; Maloney, S.P.; Pimiento, J.M.; Fancher, T.T.; Magri, D.; Westvik, H.H.; Nishibe, T.; Velazquez, O.C.; et al. Limb ischemia after iliac ligation in aged mice stimulates angiogenesis without arteriogenesis. J. Vasc. Surg. 2009, 49, 464-473. [CrossRef] [PubMed]

36. Brechot, N.; Gomez, E.; Bignon, M.; Khallou-Laschet, J.; Dussiot, M.; Cazes, A.; Alanio-Brechot, C.; Durand, M.; Philippe, J.; Silvestre, J.S.; et al. Modulation of macrophage activation state protects tissue from necrosis during critical limb ischemia in thrombospondin-1-deficient mice. PLoS ONE 2008, 3, e3950. [CrossRef]

37. Crawford, R.S.; Albadawi, H.; Robaldo, A.; Peck, M.A.; Abularrage, C.J.; Yoo, H.J.; Lamuraglia, G.M.; Watkins, M.T. Divergent systemic and local inflammatory response to hind limb demand ischemia in wild-type and ApoE ${ }^{-/-}$mice. J. Surg. Res. 2013, 183, 952-962. [CrossRef]

38. Rishi, M.T.; Selvaraju, V.; Thirunavukkarasu, M.; Shaikh, I.A.; Takeda, K.; Fong, G.H.; Palesty, J.A.; Sanchez, J.A.; Maulik, N. Deletion of prolyl hydroxylase domain proteins (PHD1, PHD3) stabilizes hypoxia inducible factor-1 alpha, promotes neovascularization, and improves perfusion in a murine model of hind-limb ischemia. Microvasc. Res. 2015, 97, 181-188. [CrossRef] [PubMed]

39. Yan, J.; Tie, G.; Park, B.; Yan, Y.; Nowicki, P.T.; Messina, L.M. Recovery from hind limb ischemia is less effective in type 2 than in type 1 diabetic mice: Roles of endothelial nitric oxide synthase and endothelial progenitor cells. J. Vasc. Surg. 2009, 50, 1412-1422. [CrossRef] [PubMed]

40. MacAskill, M.G.; Saif, J.; Condie, A.; Jansen, M.A.; MacGillivray, T.J.; Tavares, A.A.S.; Fleisinger, L.; Spencer, H.L.; Besnier, M.; Martin, E.; et al. Robust Revascularization in Models of Limb Ischemia Using a Clinically Translatable Human Stem Cell-Derived Endothelial Cell Product. Mol. Ther. 2018, 26, 1669-1684. [CrossRef]

41. Rojas-Torres, M.; Jiménez-Palomares, M.; Martín-Ramírez, J.; Beltrán-Camacho, L.; Sánchez-Gomar, I.; Eslava-Alcon, S.; RosalVela, A.; Gavaldá, S.; Durán-Ruiz, M.C. REX-001, a BM-MNC Enriched Solution, Induces Revascularization of Ischemic Tissues in a Murine Model of Chronic Limb-Threatening Ischemia. Front. Cell Dev. Biol. 2020, 8, 1546. [CrossRef]

42. Creane, M.; Howard, L.; O'Brien, T.; Coleman, C.M. Biodistribution and retention of locally administered human mesenchymal stromal cells: Quantitative polymerase chain reaction-based detection of human DNA in murine organs. Cytotherapy 2017, 19, 384-394. [CrossRef]

43. Thomas, D.; Thirumaran, A.; Mallard, B.; Chen, X.; Browne, S.; Wheatley, A.M.; O’Brien, T.; Pandit, A. Variability in Endogenous Perfusion Recovery of Immunocompromised Mouse Models of Limb Ischemia. Tissue. Eng. Part C Methods 2016, 22, 370-381. [CrossRef] [PubMed]

44. Goto, T.; Fukuyama, N.; Aki, A.; Kanabuchi, K.; Kimura, K.; Taira, H.; Tanaka, E.; Wakana, N.; Mori, H.; Inoue, H. Search for appropriate experimental methods to create stable hind-limb ischemia in mouse. Tokai J. Exp. Clin. Med. 2006, 31, 128-132.

45. Krishna, S.M.; Omer, S.M.; Golledge, J. Evaluation of the clinical relevance and limitations of current pre-clinical models of peripheral artery disease. Clin. Sci. 2016, 130, 127-150. [CrossRef] [PubMed]

46. Hellingman, A.A.; Bastiaansen, A.J.; de Vries, M.R.; Seghers, L.; Lijkwan, M.A.; Lowik, C.W.; Hamming, J.F.; Quax, P.H. Variations in surgical procedures for hind limb ischaemia mouse models result in differences in collateral formation. Eur. J. Vasc. Endovasc. Surg. 2010, 40, 796-803. [CrossRef] [PubMed] 
47. Beltran-Camacho, L.; Jimenez-Palomares, M.; Rojas-Torres, M.; Sanchez-Gomar, I.; Rosal-Vela, A.; Eslava-Alcon, S.; Perez-Segura, M.C.; Serrano, A.; Antequera-Gonzalez, B.; Alonso-Pinero, J.A.; et al. Identification of the initial molecular changes in response to circulating angiogenic cells-mediated therapy in critical limb ischemia. Stem. Cell. Res. Ther. 2020, 11, 106. [CrossRef]

48. Kochi, T.; Imai, Y.; Takeda, A.; Watanabe, Y.; Mori, S.; Tachi, M.; Kodama, T. Characterization of the arterial anatomy of the murine hindlimb: Functional role in the design and understanding of ischemia models. PLoS ONE 2013, 8, e84047. [CrossRef]

49. Aref, Z.; de Vries, M.R.; Quax, P.H.A. Variations in Surgical Procedures for Inducing Hind Limb Ischemia in Mice and the Impact of These Variations on Neovascularization Assessment. Int. J. Mol. Sci. 2019, 20, 3704. [CrossRef]

50. Fukino, K.; Sata, M.; Seko, Y.; Hirata, Y.; Nagai, R. Genetic background influences therapeutic effectiveness of VEGF. Biochem Biophys Res. Commun. 2003, 310, 143-147. [CrossRef]

51. Nossent, A.Y.; Bastiaansen, A.J.; Peters, E.A.; de Vries, M.R.; Aref, Z.; Welten, S.M.; de Jager, S.C.; van der Pouw Kraan, T.C.; Quax, P.H. CCR7-CCL19/CCL21 Axis is Essential for Effective Arteriogenesis in a Murine Model of Hindlimb Ischemia. J. Am. Heart Assoc. 2017, 6, e005281. [CrossRef] [PubMed]

52. Lejay, A.; Choquet, P.; Thaveau, F.; Singh, F.; Schlagowski, A.; Charles, A.L.; Laverny, G.; Metzger, D.; Zoll, J.; Chakfe, N.; et al. A new murine model of sustainable and durable chronic critical limb ischemia fairly mimicking human pathology. Eur. J. Vasc. Endovasc. Surg. 2015, 49, 205-212. [CrossRef] [PubMed]

53. Krishna, S.M.; Omer, S.M.; Li, J.; Morton, S.K.; Jose, R.J.; Golledge, J. Development of a two-stage limb ischemia model to better simulate human peripheral artery disease. Sci. Rep. 2020, 10, 3449. [CrossRef]

54. Han, S.S.; Jin, Z.; Lee, B.S.; Han, J.S.; Choi, J.J.; Park, S.J.; Chung, H.M.; Mukhtar, A.S.; Moon, S.H.; Kang, S.W. Reproducible hindlimb ischemia model based on photochemically induced thrombosis to evaluate angiogenic effects. Microvasc. Res. 2019, 126, 103912. [CrossRef]

55. Parikh, P.P.; Castilla, D.; Lassance-Soares, R.M.; Shao, H.; Regueiro, M.; Li, Y.; Vazquez-Padron, R.; Webster, K.A.; Liu, Z.J.; Velazquez, O.C. A Reliable Mouse Model of Hind limb Gangrene. Ann. Vasc. Surg. 2018, 48, 222-232. [CrossRef]

56. Sligar, A.D.; Howe, G.; Goldman, J.; Felli, P.; Karanam, V.; Smalling, R.W.; Baker, A.B. Preclinical Model of Hind Limb Ischemia in Diabetic Rabbits. J. Vis. Exp. 2019, 148, e58964. [CrossRef] [PubMed]

57. Zampetaki, A.; Kirton, J.P.; Xu, Q. Vascular repair by endothelial progenitor cells. Cardiovasc. Res. 2008, 78, 413-421. [CrossRef]

58. van der Kwast, R.; Quax, P.H.A.; Nossent, A.Y. An Emerging Role for isomiRs and the microRNA Epitranscriptome in Neovascularization. Cells. 2019, 9, 61. [CrossRef]

59. Cooke, J.P.; Meng, S. Vascular Regeneration in Peripheral Artery Disease. Arterioscler Thromb. Vasc. Biol. 2020, 40, 1627-1634. [CrossRef]

60. Czapla, J.; Cichon, T.; Pilny, E.; Jarosz-Biej, M.; Matuszczak, S.; Drzyzga, A.; Krakowczyk, L.; Smolarczyk, R. Adipose tissuederived stromal cells stimulated macrophages-endothelial cells interactions promote effective ischemic muscle neovascularization. Eur. J. Pharmacol. 2020, 883, 173354. [CrossRef]

61. Lin, R.Z.; Lee, C.N.; Moreno-Luna, R.; Neumeyer, J.; Piekarski, B.; Zhou, P.; Moses, M.A.; Sachdev, M.; Pu, W.T.; Emani, S.; et al. Host non-inflammatory neutrophils mediate the engraftment of bioengineered vascular networks. Nat. Biomed. Eng. 2017, 1.

62. Limbourg, A.; von Felden, J.; Jagavelu, K.; Krishnasamy, K.; Napp, L.C.; Kapopara, P.R.; Gaestel, M.; Schieffer, B.; Bauersachs, J.; Limbourg, F.P.; et al. MAP-Kinase Activated Protein Kinase 2 Links Endothelial Activation and Monocyte/macrophage Recruitment in Arteriogenesis. PLoS ONE 2015, 10, e0138542. [CrossRef] [PubMed]

63. Lin, R.Z.; Chen, Y.C.; Moreno-Luna, R.; Khademhosseini, A.; Melero-Martin, J.M. Transdermal regulation of vascular network bioengineering using a photopolymerizable methacrylated gelatin hydrogel. Biomaterials 2013, 34, 6785-6796. [CrossRef]

64. Powell, R.J.; Simons, M.; Mendelsohn, F.O.; Daniel, G.; Henry, T.D.; Koga, M.; Morishita, R.; Annex, B.H. Results of a double-blind, placebo-controlled study to assess the safety of intramuscular injection of hepatocyte growth factor plasmid to improve limb perfusion in patients with critical limb ischemia. Circulation 2008, 118, 58-65. [CrossRef] [PubMed]

65. Yla-Herttuala, S.; Alitalo, K. Gene transfer as a tool to induce therapeutic vascular growth. Nat. Med. 2003, 9, 694-701. [CrossRef]

66. Menasche, P. Cell therapy for peripheral arterial disease. Curr. Opin. Mol. Ther. 2010, 12, 538-545. [PubMed]

67. Schmidt, C.A.; Amorese, A.J.; Ryan, T.E.; Goldberg, E.J.; Tarpey, M.D.; Green, T.D.; Karnekar, R.R.; Yamaguchi, D.J.; Spangenburg, E.E.; McClung, J.M. Strain-Dependent Variation in Acute Ischemic Muscle Injury. Am. J. Pathol. 2018, 188, 1246-1262. [CrossRef] [PubMed]

68. Asahara, T.; Kawamoto, A. Endothelial progenitor cells for postnatal vasculogenesis. Am. J. Physiol. Cell Physiol. 2004, 287, C572-C579. [CrossRef]

69. Cunha, F.F.; Martins, L.; Martin, P.K.; Stilhano, R.S.; Han, S.W. A comparison of the reparative and angiogenic properties of mesenchymal stem cells derived from the bone marrow of BALB/c and C57/BL6 mice in a model of limb ischemia. Stem. Cell Res. Ther. 2013, 4, 86. [CrossRef]

70. Garcia-Vazquez, M.D.; Herrero de la Parte, B.; Garcia-Alonso, I.; Morales, M.C. Analysis of Biological Properties of Human Adult Mesenchymal Stem Cells and Their Effect on Mouse Hind Limb Ischemia]. J. Vasc. Res. 2019, 56, 77-91. [CrossRef]

71. Nammian, P.; Asadi-Yousefabad, S.L.; Daneshi, S.; Sheikhha, M.H.; Tabei, S.M.B.; Razban, V. Comparative analysis of mouse bone marrow and adipose tissue mesenchymal stem cells for critical limb ischemia cell therapy. Stem. Cell Res. Ther. 2021, 12, 58. [CrossRef] 
72. Rossi, E.; Smadja, D.; Goyard, C.; Cras, A.; Dizier, B.; Bacha, N.; Lokajczyk, A.; Guerin, C.L.; Gendron, N.; Planquette, B.; et al. Co-injection of mesenchymal stem cells with endothelial progenitor cells accelerates muscle recovery in hind limb ischemia through an endoglin-dependent mechanism. Thromb. Haemost. 2017, 117, 1908-1918. [CrossRef]

73. Lian, W.; Hu, X.; Pan, L.; Han, S.; Cao, C.; Jia, Z.; Li, M. Human primary CD34(+) cells transplantation for critical limb ischemia. J. Clin. Lab. Anal. 2018, 32, e22569. [CrossRef] [PubMed]

74. Kalka, C.; Masuda, H.; Takahashi, T.; Kalka-Moll, W.M.; Silver, M.; Kearney, M.; Li, T.; Isner, J.M.; Asahara, T. Transplantation of ex vivo expanded endothelial progenitor cells for therapeutic neovascularization. Proc. Natl. Acad. Sci. USA 2000, 97, 3422-3427. [CrossRef] [PubMed]

75. Urbich, C.; Heeschen, C.; Aicher, A.; Dernbach, E.; Zeiher, A.M.; Dimmeler, S. Relevance of monocytic features for neovascularization capacity of circulating endothelial progenitor cells. Circulation 2003, 108, 2511-2516. [CrossRef]

76. Zhao, W.N.; Xu, S.Q.; Liang, J.F.; Peng, L.; Liu, H.L.; Wang, Z.; Fang, Q.; Wang, M.; Yin, W.Q.; Zhang, W.J.; et al. Endothelial progenitor cells from human fetal aorta cure diabetic foot in a rat model. Metabolism 2016, 65, 1755-1767. [CrossRef] [PubMed]

77. Yoon, C.H.; Hur, J.; Park, K.W.; Kim, J.H.; Lee, C.S.; Oh, I.Y.; Kim, T.Y.; Cho, H.J.; Kang, H.J.; Chae, I.H.; et al. Synergistic neovascularization by mixed transplantation of early endothelial progenitor cells and late outgrowth endothelial cells: The role of angiogenic cytokines and matrix metalloproteinases. Circulation 2005, 112, 1618-1627. [CrossRef] [PubMed]

78. Foubert, P.; Matrone, G.; Souttou, B.; Lere-Dean, C.; Barateau, V.; Plouet, J.; Le Ricousse-Roussanne, S.; Levy, B.I.; Silvestre, J.S.; Tobelem, G. Coadministration of endothelial and smooth muscle progenitor cells enhances the efficiency of proangiogenic cell-based therapy. Circ. Res. 2008, 103, 751-760. [CrossRef]

79. Shintani, S.; Murohara, T.; Ikeda, H.; Ueno, T.; Sasaki, K.; Duan, J.; Imaizumi, T. Augmentation of postnatal neovascularization with autologous bone marrow transplantation. Circulation 2001, 103, 897-903. [CrossRef]

80. de Nigris, F.; Williams-Ignarro, S.; Sica, V.; D'Armiento, F.P.; Lerman, L.O.; Byrns, R.E.; Sica, G.; Fiorito, C.; Ignarro, L.J.; Napoli, C. Therapeutic effects of concurrent autologous bone marrow cell infusion and metabolic intervention in ischemia-induced angiogenesis in the hypercholesterolemic mouse hindlimb. Int. J. Cardiol. 2007, 117, 238-243. [CrossRef] [PubMed]

81. Jeon, O.; Song, S.J.; Bhang, S.H.; Choi, C.Y.; Kim, M.J.; Kim, B.S. Additive effect of endothelial progenitor cell mobilization and bone marrow mononuclear cell transplantation on angiogenesis in mouse ischemic limbs. J. Biomed. Sci. 2007, 14, 323-330. [CrossRef]

82. Gan, L.; Matsuura, H.; Ichiki, T.; Yin, X.; Miyazaki, R.; Hashimoto, T.; Cui, J.; Takeda, K.; Sunagawa, K. Improvement of neovascularization capacity of bone marrow mononuclear cells from diabetic mice by ex vivo pretreatment with resveratrol. Hypertens. Res. 2009, 32, 542-547. [CrossRef] [PubMed]

83. Liu, Q.; Chen, Z.; Terry, T.; McNatt, J.M.; Willerson, J.T.; Zoldhelyi, P. Intra-arterial transplantation of adult bone marrow cells restores blood flow and regenerates skeletal muscle in ischemic limbs. Vasc. Endovascular. Surg. 2009, 43, 433-443. [CrossRef]

84. Brenes, R.A.; Jadlowiec, C.C.; Bear, M.; Hashim, P.; Protack, C.D.; Li, X.; Lv, W.; Collins, M.J.; Dardik, A. Toward a mouse model of hind limb ischemia to test therapeutic angiogenesis. J. Vasc. Surg. 2012, 56, 1669-1679; discussion 1679. [CrossRef] [PubMed]

85. Reis, P.E.; de Carvalho, L.P.; Yasumura, E.; da Silva, F.H.; Garcia, B.C.; Beutel, A.; Sacramento, C.B.; Baptista-Silva, J.C.; de Campos, R.R.; Takiya, C.M.; et al. Impact of angiogenic therapy in the treatment of critical lower limb ischemia in an animal model. Vasc. Endovascular. Surg. 2014, 48, 207-216. [CrossRef] [PubMed]

86. Kuwahara, G.; Nishinakamura, H.; Kojima, D.; Tashiro, T.; Kodama, S. GM-CSF treated F4/80+ BMCs improve murine hind limb ischemia similar to M-CSF differentiated macrophages. PLoS ONE 2014, 9, e106987. [CrossRef] [PubMed]

87. Capoccia, B.J.; Robson, D.L.; Levac, K.D.; Maxwell, D.J.; Hohm, S.A.; Neelamkavil, M.J.; Bell, G.I.; Xenocostas, A.; Link, D.C.; Piwnica-Worms, D.; et al. Revascularization of ischemic limbs after transplantation of human bone marrow cells with high aldehyde dehydrogenase activity. Blood 2009, 113, 5340-5351. [CrossRef]

88. Rahnemai-Azar, A.; D’Ippolito, G.; Gomez, L.A.; Reiner, T.; Vazquez-Padron, R.I.; Perez-Stable, C.; Roos, B.A.; Pham, S.M.; Schiller, P.C. Human marrow-isolated adult multilineage-inducible (MIAMI) cells protect against peripheral vascular ischemia in a mouse model. Cytotherapy 2011, 13, 179-192. [CrossRef]

89. Li, S.; Zhou, B.; Han, Z.C. Therapeutic neovascularization by transplantation of mobilized peripheral blood mononuclear cells for limb ischemia. A comparison between CD34+ and CD34- mononuclear cells. Thromb. Haemost. 2006, 95, 301-311. [PubMed]

90. Padilla, L.; Arguero-Sanchez, R.; Rodriguez-Trejo, J.M.; Carranza-Castro, P.H.; Suarez-Cuenca, J.A.; Polaco-Castillo, J.; DiSilvioLopez, M.; Lopez-Gutierrez, J.; Olguin-Juarez, H.; Hernandez-Patricio, A.; et al. Effect of autologous transplant of peripheral blood mononuclear cells in combination with proangiogenic factors during experimental revascularization of lower limb ischemia. J. Tissue. Eng. Regen. Med. 2020, 14, 600-608. [CrossRef]

91. Liu, J.; Qiu, P.; Qin, J.; Wu, X.; Wang, X.; Yang, X.; Li, B.; Zhang, W.; Ye, K.; Peng, Z.; et al. Allogeneic adipose-derived stem cells promote ischemic muscle repair by inducing M2 macrophage polarization via the HIF-1alpha/IL-10 pathway. Stem. Cells 2020, 38, 1307-1320. [PubMed]

92. Rybalko, V.; Hsieh, P.L.; Ricles, L.M.; Chung, E.; Farrar, R.P.; Suggs, L.J. Therapeutic potential of adipose-derived stem cells and macrophages for ischemic skeletal muscle repair. Regen. Med. 2017, 12, 153-167. [CrossRef] [PubMed]

93. Jin, E.; Chae, D.S.; Son, M.; Kim, S.W. Angiogenic characteristics of human stromal vascular fraction in ischemic hindlimb. Int. J. Cardiol. 2017, 234, 38-47. [CrossRef] [PubMed]

94. Prather, W.R.; Toren, A.; Meiron, M.; Ofir, R.; Tschope, C.; Horwitz, E.M. The role of placental-derived adherent stromal cell (PLX-PAD) in the treatment of critical limb ischemia. Cytotherapy 2009, 11, 427-434. [CrossRef] [PubMed] 
95. Zahavi-Goldstein, E.; Blumenfeld, M.; Fuchs-Telem, D.; Pinzur, L.; Rubin, S.; Aberman, Z.; Sher, N.; Ofir, R. Placenta-derived PLX-PAD mesenchymal-like stromal cells are efficacious in rescuing blood flow in hind limb ischemia mouse model by a doseand site-dependent mechanism of action. Cytotherapy 2017, 19, 1438-1446. [CrossRef] [PubMed]

96. Soria-Juan, B.; Escacena, N.; Capilla-Gonzalez, V.; Aguilera, Y.; Llanos, L.; Tejedo, J.R.; Bedoya, F.J.; Juan, V.; De la Cuesta, A.; Ruiz-Salmeron, R.; et al. Cost-Effective, Safe, and Personalized Cell Therapy for Critical Limb Ischemia in Type 2 Diabetes Mellitus. Front Immunol. 2019, 10, 1151. [CrossRef]

97. Kim, Y.; Kim, H.; Cho, H.; Bae, Y.; Suh, K.; Jung, J. Direct comparison of human mesenchymal stem cells derived from adipose tissues and bone marrow in mediating neovascularization in response to vascular ischemia. Cell Physiol. Biochem. 2007, 20, 867-876. [CrossRef]

98. Wang, Z.; Zheng, L.; Lian, C.; Qi, Y.; Li, W.; Wang, S. Human Umbilical Cord-Derived Mesenchymal Stem Cells Relieve Hind Limb Ischemia by Promoting Angiogenesis in Mice. Stem. Cells Dev. 2019, 28, 1384-1397. [CrossRef] [PubMed]

99. Mathew, S.A.; Naik, C.; Cahill, P.A.; Bhonde, R.R. Placental mesenchymal stromal cells as an alternative tool for therapeutic angiogenesis. Cell Mol. Life Sci. 2020, 77, 253-265. [CrossRef] [PubMed]

100. Cobellis, G.; Maione, C.; Botti, C.; Coppola, A.; Silvestroni, A.; Lillo, S.; Schiavone, V.; Molinari, A.M.; Sica, V. Beneficial effects of VEGF secreted from stromal cells in supporting endothelial cell functions: Therapeutic implications for critical limb ischemia. Cell Transplant. 2010, 19, 1425-1437. [CrossRef]

101. Song, Y.; Zhang, T.J.; Li, Y.; Gao, Y. Mesenchymal Stem Cells Decrease M1/M2 Ratio and Alleviate Inflammation to Improve Limb Ischemia in Mice. Med. Sci. Monit. 2020, 26, e923287. [CrossRef]

102. Asahara, T.; Murohara, T.; Sullivan, A.; Silver, M.; van der Zee, R.; Li, T.; Witzenbichler, B.; Schatteman, G.; Isner, J.M. Isolation of putative progenitor endothelial cells for angiogenesis. Science 1997, 275, 964-967. [CrossRef]

103. Patel, J.; Donovan, P.; Khosrotehrani, K. Concise Review: Functional Definition of Endothelial Progenitor Cells: A Molecular Perspective. Stem Cells Transl. Med. 2016, 5, 1302-1306. [CrossRef]

104. Edwards, N.; Langford-Smith, A.W.W.; Wilkinson, F.L.; Alexander, M.Y. Endothelial Progenitor Cells: New Targets for Therapeutics for Inflammatory Conditions with High Cardiovascular Risk. Front. Med. 2018, 5, 200. [CrossRef] [PubMed]

105. Chopra, H.H.M.K.; Kwong, D.L.; Zhang, C.F.; Pow, E.H.N. Insights into Endothelial Progenitor Cells: Origin, Classification, Potentials, and prospects. Stem. Cell Int. 2018, 2018, 24. [CrossRef]

106. Medina, R.J.; Barber, C.L.; Sabatier, F.; Dignat-George, F.; Melero-Martin, J.M.; Khosrotehrani, K.; Ohneda, O.; Randi, A.M.; Chan, J.K.Y.; Yamaguchi, T.; et al. Endothelial Progenitors: A Consensus Statement on Nomenclature. Stem. Cells Transl. Med. 2017, 6, 1316-1320. [CrossRef]

107. Stitt, A.W.; O’Neill, C.L.; O'Doherty, M.T.; Archer, D.B.; Gardiner, T.A.; Medina, R.J. Vascular stem cells and ischaemic retinopathies. Prog. Retin. Eye. Res. 2011, 30, 149-166. [CrossRef]

108. Ziegelhoeffer, T.; Fernandez, B.; Kostin, S.; Heil, M.; Voswinckel, R.; Helisch, A.; Schaper, W. Bone marrow-derived cells do not incorporate into the adult growing vasculature. Circ. Res. 2004, 94, 230-238. [CrossRef] [PubMed]

109. Yoder, M.C.; Mead, L.E.; Prater, D.; Krier, T.R.; Mroueh, K.N.; Li, F.; Krasich, R.; Temm, C.J.; Prchal, J.T.; Ingram, D.A. Redefining endothelial progenitor cells via clonal analysis and hematopoietic stem/progenitor cell principals. Blood 2007, 109, 1801-1809. [CrossRef] [PubMed]

110. Eslava-Alcon, S.; Extremera-Garcia, M.J.; Sanchez-Gomar, I.; Beltran-Camacho, L.; Rosal-Vela, A.; Munoz, J.; Ibarz, N.; AlonsoPinero, J.A.; Rojas-Torres, M.; Jimenez-Palomares, M.; et al. Atherosclerotic Pre-Conditioning Affects the Paracrine Role of Circulating Angiogenic Cells Ex-Vivo. Int. J. Mol. Sci. 2020, 21, 5256. [CrossRef]

111. Le Ricousse-Roussanne, S.; Barateau, V.; Contreres, J.O.; Boval, B.; Kraus-Berthier, L.; Tobelem, G. Ex vivo differentiated endothelial and smooth muscle cells from human cord blood progenitors home to the angiogenic tumor vasculature. Cardiovasc. Res. 2004, 62, 176-184. [CrossRef]

112. Fowkes, F.G.; Aboyans, V.; Fowkes, F.J.; McDermott, M.M.; Sampson, U.K.; Criqui, M.H. Peripheral artery disease: Epidemiology and global perspectives. Nat. Rev. Cardiol. 2017, 14, 156-170. [CrossRef] [PubMed]

113. Ratajczak, M.Z.; Zuba-Surma, E.K.; Machalinski, B.; Ratajczak, J.; Kucia, M. Very small embryonic-like (VSEL) stem cells: Purification from adult organs, characterization, and biological significance. Stem. Cell Rev. 2008, 4, 89-99. [CrossRef] [PubMed]

114. Amann, B.; Luedemann, C.; Ratei, R.; Schmidt-Lucke, J.A. Autologous bone marrow cell transplantation increases leg perfusion and reduces amputations in patients with advanced critical limb ischemia due to peripheral artery disease. Cell Transplant. 2009, 18, 371-380. [CrossRef]

115. Fadini, G.P.; Agostini, C.; Avogaro, A. Autologous stem cell therapy for peripheral arterial disease meta-analysis and systematic review of the literature. Atherosclerosis 2010, 209, 10-17. [CrossRef]

116. Guo, J.; Guo, L.; Cui, S.; Tong, Z.; Dardik, A.; Gu, Y. Autologous bone marrow-derived mononuclear cell therapy in Chinese patients with critical limb ischemia due to thromboangiitis obliterans: 10-year results. Stem. Cell Res. Ther. 2018, 9, 43. [CrossRef]

117. Idei, N.; Soga, J.; Hata, T.; Fujii, Y.; Fujimura, N.; Mikami, S.; Maruhashi, T.; Nishioka, K.; Hidaka, T.; Kihara, Y.; et al. Limb ischemia: A comparison of atherosclerotic peripheral arterial disease and Buerger disease. Circ. Cardiovasc. Interv. 2011, 4, 15-25. [CrossRef]

118. Liang, T.W.; Jester, A.; Motaganahalli, R.L.; Wilson, M.G.; G'Sell, P.; Akingba, G.A.; Fajardo, A.; Murphy, M.P. Autologous bone marrow mononuclear cell therapy for critical limb ischemia is effective and durable. J. Vasc. Surg. 2016, 63, 1541-1545. [CrossRef] 
119. Murphy, M.P.; Lawson, J.H.; Rapp, B.M.; Dalsing, M.C.; Klein, J.; Wilson, M.G.; Hutchins, G.D.; March, K.L. Autologous bone marrow mononuclear cell therapy is safe and promotes amputation-free survival in patients with critical limb ischemia. J. Vasc. Surg. 2011, 53, 1565-1574 e1. [CrossRef]

120. Ruiz-Salmeron, R.; de la Cuesta-Diaz, A.; Constantino-Bermejo, M.; Perez-Camacho, I.; Marcos-Sanchez, F.; Hmadcha, A.; Soria, B. Angiographic demonstration of neoangiogenesis after intra-arterial infusion of autologous bone marrow mononuclear cells in diabetic patients with critical limb ischemia. Cell Transplant. 2011, 20, 1629-1639. [CrossRef] [PubMed]

121. Wahid, F.S.A.; Ismail, N.A.; Wan Jamaludin, W.F.; Muhamad, N.A.; Mohamad Idris, M.A.; Lai, N.M. Efficacy and Safety of Autologous Cell-based Therapy in Patients with No-option Critical Limb Ischaemia: A Meta-Analysis. Curr. Stem. Cell Res. Ther. 2018, 13, 265-283. [CrossRef] [PubMed]

122. Yusoff, F.M.; Kajikawa, M.; Matsui, S.; Hashimoto, H.; Kishimoto, S.; Maruhashi, T.; Chowdhury, M.; Noma, K.; Nakashima, A.; Kihara, Y.; et al. Review of the Long-term Effects of Autologous Bone-Marrow Mononuclear Cell Implantation on Clinical Outcomes in Patients with Critical Limb Ischemia. Sci. Rep. 2019, 9, 7711. [CrossRef]

123. Kumar, A.; Prasad, M.; Jali, V.P.; Pandit, A.K.; Misra, S.; Kumar, P.; Chakravarty, K.; Kathuria, P.; Gulati, A. Bone marrow mononuclear cell therapy in ischaemic stroke: A systematic review. Acta. Neurol. Scand. 2017, 135, 496-506. [CrossRef]

124. Kikuchi-Taura, A.; Okinaka, Y.; Takeuchi, Y.; Ogawa, Y.; Maeda, M.; Kataoka, Y.; Yasui, T.; Kimura, T.; Gul, S.; Claussen, C.; et al. Bone Marrow Mononuclear Cells Activate Angiogenesis via Gap Junction-Mediated Cell-Cell Interaction. Stroke 2020, 51, 1279-1289. [CrossRef]

125. Huang, P.; Li, S.; Han, M.; Xiao, Z.; Yang, R.; Han, Z.C. Autologous transplantation of granulocyte colony-stimulating factormobilized peripheral blood mononuclear cells improves critical limb ischemia in diabetes. Diabetes. Care 2005, 28, 2155-2160. [CrossRef] [PubMed]

126. Kawamura, A.; Horie, T.; Tsuda, I.; Abe, Y.; Yamada, M.; Egawa, H.; Iida, J.; Sakata, H.; Onodera, K.; Tamaki, T.; et al. Clinical study of therapeutic angiogenesis by autologous peripheral blood stem cell (PBSC) transplantation in 92 patients with critically ischemic limbs. J. Artif. Organs. 2006, 9, 226-233. [CrossRef]

127. Mohammadzadeh, L.; Samedanifard, S.H.; Keshavarzi, A.; Alimoghaddam, K.; Larijani, B.; Ghavamzadeh, A.; Ahmadi, A.S.; Shojaeifard, A.; Ostadali, M.R.; Sharifi, A.M.; et al. Therapeutic outcomes of transplanting autologous granulocyte colonystimulating factor-mobilised peripheral mononuclear cells in diabetic patients with critical limb ischaemia. Exp. Clin. Endocrinol. Diabetes 2013, 121, 48-53. [CrossRef] [PubMed]

128. Ozturk, A.; Kucukardali, Y.; Tangi, F.; Erikci, A.; Uzun, G.; Bashekim, C.; Sen, H.; Terekeci, H.; Narin, Y.; Ozyurt, M.; et al. Therapeutical potential of autologous peripheral blood mononuclear cell transplantation in patients with type 2 diabetic critical limb ischemia. J. Diabetes Complicat. 2012, 26, 29-33. [CrossRef] [PubMed]

129. Dubsky, M.; Jirkovska, A.; Bem, R.; Fejfarova, V.; Pagacova, L.; Sixta, B.; Varga, M.; Langkramer, S.; Sykova, E.; Jude, E.B. Both autologous bone marrow mononuclear cell and peripheral blood progenitor cell therapies similarly improve ischaemia in patients with diabetic foot in comparison with control treatment. Diabetes Metab. Res. Rev. 2013, 29, 369-376. [CrossRef] [PubMed]

130. Minamino, T.; Toko, H.; Tateno, K.; Nagai, T.; Komuro, I. Peripheral-blood or bone-marrow mononuclear cells for therapeutic angiogenesis? Lancet 2002, 360, 2083-2084; author reply 2084. [CrossRef]

131. Capiod, J.C.; Tournois, C.; Vitry, F.; Sevestre, M.A.; Daliphard, S.; Reix, T.; Nguyen, P.; Lefrere, J.J.; Pignon, B. Characterization and comparison of bone marrow and peripheral blood mononuclear cells used for cellular therapy in critical leg ischaemia: Towards a new cellular product. Vox. Sang. 2009, 96, 256-265. [CrossRef] [PubMed]

132. Mazini, L.; Rochette, L.; Amine, M.; Malka, G. Regenerative Capacity of Adipose Derived Stem Cells (ADSCs), Comparison with Mesenchymal Stem Cells (MSCs). Int. J. Mol. Sci. 2019, 20, 2523. [CrossRef]

133. Rehman, J.; Traktuev, D.; Li, J.; Merfeld-Clauss, S.; Temm-Grove, C.J.; Bovenkerk, J.E.; Pell, C.L.; Johnstone, B.H.; Considine, R.V.; March, K.L. Secretion of angiogenic and antiapoptotic factors by human adipose stromal cells. Circulation 2004, 109, 1292-1298. [CrossRef]

134. Safford, K.M.; Hicok, K.C.; Safford, S.D.; Halvorsen, Y.D.; Wilkison, W.O.; Gimble, J.M.; Rice, H.E. Neurogenic differentiation of murine and human adipose-derived stromal cells. Biochem. Biophys. Res. Commun. 2002, 294, 371-379. [CrossRef]

135. Dragoo, J.L.; Choi, J.Y.; Lieberman, J.R.; Huang, J.; Zuk, P.A.; Zhang, J.; Hedrick, M.H.; Benhaim, P. Bone induction by BMP-2 transduced stem cells derived from human fat. J. Orthop. Res. 2003, 21, 622-629. [CrossRef]

136. Zhi, K.; Gao, Z.; Bai, J.; Wu, Y.; Zhou, S.; Li, M.; Qu, L. Application of adipose-derived stem cells in critical limb ischemia. Front Biosci. 2014, 19, 768-776. [CrossRef] [PubMed]

137. Han, S.; Sun, H.M.; Hwang, K.C.; Kim, S.W. Adipose-Derived Stromal Vascular Fraction Cells: Update on Clinical Utility and Efficacy. Crit. Rev. Eukaryot. Gene. Expr. 2015, 25, 145-152. [CrossRef]

138. Hong, S.J.; Traktuev, D.O.; March, K.L. Therapeutic potential of adipose-derived stem cells in vascular growth and tissue repair. Curr. Opin. Organ. Transplant. 2010, 15, 86-91. [CrossRef] [PubMed]

139. Katagiri, T.; Kondo, K.; Shibata, R.; Hayashida, R.; Shintani, S.; Yamaguchi, S.; Shimizu, Y.; Unno, K.; Kikuchi, R.; Kodama, A.; et al. Therapeutic angiogenesis using autologous adipose-derived regenerative cells in patients with critical limb ischaemia in Japan: A clinical pilot study. Sci. Rep. 2020, 10, 16045. [CrossRef]

140. Qadura, M.; Terenzi, D.C.; Verma, S.; Al-Omran, M.; Hess, D.A. Concise Review: Cell Therapy for Critical Limb Ischemia: An Integrated Review of Preclinical and Clinical Studies. Stem. Cells 2018, 36, 161-171. [CrossRef] [PubMed] 
141. Silvestre, J.S. Pro-angiogenic cell-based therapy for the treatment of ischemic cardiovascular diseases. Thromb. Res. 2012, 130 (Suppl. 1), S90-S94. [CrossRef]

142. Tateishi-Yuyama, E.; Matsubara, H.; Murohara, T.; Ikeda, U.; Shintani, S.; Masaki, H.; Amano, K.; Kishimoto, Y.; Yoshimoto, K.; Akashi, H.; et al. Therapeutic angiogenesis for patients with limb ischaemia by autologous transplantation of bone-marrow cells: A pilot study and a randomised controlled trial. Lancet 2002, 360, 427-435. [CrossRef]

143. Norgren, L.; Weiss, N.; Nikol, S.; Hinchliffe, R.J.; Lantis, J.C.; Patel, M.R.; Reinecke, H.; Ofir, R.; Rosen, Y.; Peres, D.; et al. PLX-PAD Cell Treatment of Critical Limb Ischaemia: Rationale and Design of the PACE Trial. Eur. J. Vasc. Endovasc. Surg. 2019, 57, 538-545. [CrossRef]

144. De Angelis, B.; Gentile, P.; Orlandi, F.; Bocchini, I.; Di Pasquali, C.; Agovino, A.; Gizzi, C.; Patrizi, F.; Scioli, M.G.; Orlandi, A.; et al. Limb rescue: A new autologous-peripheral blood mononuclear cells technology in critical limb ischemia and chronic ulcers. Tissue. Eng. Part C Methods 2015, 21, 423-435. [CrossRef] [PubMed]

145. Arai, M.; Misao, Y.; Nagai, H.; Kawasaki, M.; Nagashima, K.; Suzuki, K.; Tsuchiya, K.; Otsuka, S.; Uno, Y.; Takemura, G.; et al. Granulocyte colony-stimulating factor: A noninvasive regeneration therapy for treating atherosclerotic peripheral artery disease. Circ. J. 2006, 70, 1093-1098. [CrossRef] [PubMed]

146. Huang, P.P.; Yang, X.F.; Li, S.Z.; Wen, J.C.; Zhang, Y.; Han, Z.C. Randomised comparison of G-CSF-mobilized peripheral blood mononuclear cells versus bone marrow-mononuclear cells for the treatment of patients with lower limb arteriosclerosis obliterans. Thromb. Haemost. 2007, 98, 1335-1342. [CrossRef] [PubMed]

147. Li, M.; Zhou, H.; Jin, X.; Wang, M.; Zhang, S.; Xu, L. Autologous bone marrow mononuclear cells transplant in patients with critical leg ischemia: Preliminary clinical results. Exp. Clin. Transplant 2013, 11, 435-439. [CrossRef]

148. Teraa, M.; Sprengers, R.W.; Schutgens, R.E.; Slaper-Cortenbach, I.C.; van der Graaf, Y.; Algra, A.; van der Tweel, I.; Doevendans, P.A.; Mali, W.P.; Moll, F.L.; et al. Effect of repetitive intra-arterial infusion of bone marrow mononuclear cells in patients with no-option limb ischemia: The randomized, double-blind, placebo-controlled Rejuvenating Endothelial Progenitor Cells via Transcutaneous Intra-arterial Supplementation (JUVENTAS) trial. Circulation 2015, 131, 851-860.

149. Pignon, B.; Sevestre, M.A.; Kanagaratnam, L.; Pernod, G.; Stephan, D.; Emmerich, J.; Clement, C.; Sarlon, G.; Boulon, C.; Tournois, C.; et al. Autologous Bone Marrow Mononuclear Cell Implantation and Its Impact on the Outcome of Patients With Critical Limb Ischemia- Results of a Randomized, Double-Blind, Placebo-Controlled Trial. Circ. J. 2017, 81, 1713-1720. [CrossRef] [PubMed]

150. Lu, D.; Chen, B.; Liang, Z.; Deng, W.; Jiang, Y.; Li, S.; Xu, J.; Wu, Q.; Zhang, Z.; Xie, B.; et al. Comparison of bone marrow mesenchymal stem cells with bone marrow-derived mononuclear cells for treatment of diabetic critical limb ischemia and foot ulcer: A double-blind, randomized, controlled trial. Diabetes Res. Clin. Pract. 2011, 92, 26-36. [CrossRef]

151. Dash, N.R.; Dash, S.N.; Routray, P.; Mohapatra, S.; Mohapatra, P.C. Targeting nonhealing ulcers of lower extremity in human through autologous bone marrow-derived mesenchymal stem cells. Rejuvenation Res. 2009, 12, 359-366. [CrossRef] [PubMed]

152. Gupta, P.K.; Chullikana, A.; Parakh, R.; Desai, S.; Das, A.; Gottipamula, S.; Krishnamurthy, S.; Anthony, N.; Pherwani, A.; Majumdar, A.S. A double blind randomized placebo controlled phase I/II study assessing the safety and efficacy of allogeneic bone marrow derived mesenchymal stem cell in critical limb ischemia. J. Transl. Med. 2013, 11, 143. [CrossRef]

153. Szabo, G.V.; Kovesd, Z.; Cserepes, J.; Daroczy, J.; Belkin, M.; Acsady, G. Peripheral blood-derived autologous stem cell therapy for the treatment of patients with late-stage peripheral artery disease-results of the short- and long-term follow-up. Cytotherapy 2013, 15, 1245-1252. [CrossRef]

154. Raval, A.N.; Schmuck, E.G.; Tefera, G.; Leitzke, C.; Ark, C.V.; Hei, D.; Centanni, J.M.; de Silva, R.; Koch, J.; Chappell, R.G.; et al. Bilateral administration of autologous CD133+ cells in ambulatory patients with refractory critical limb ischemia: Lessons learned from a pilot randomized, double-blind, placebo-controlled trial. Cytotherapy 2014, 16, 1720-1732. [CrossRef] [PubMed]

155. Lara-Hernandez, R.; Lozano-Vilardell, P.; Blanes, P.; Torreguitart-Mirada, N.; Galmes, A.; Besalduch, J. Safety and efficacy of therapeutic angiogenesis as a novel treatment in patients with critical limb ischemia. Ann. Vasc. Surg. 2010, 24, 287-294. [CrossRef] [PubMed]

156. Kinoshita, M.; Fujita, Y.; Katayama, M.; Baba, R.; Shibakawa, M.; Yoshikawa, K.; Katakami, N.; Furukawa, Y.; Tsukie, T.; Nagano, T.; et al. Long-term clinical outcome after intramuscular transplantation of granulocyte colony stimulating factor-mobilized CD34 positive cells in patients with critical limb ischemia. Atherosclerosis 2012, 224, 440-445. [CrossRef]

157. Dong, Z.; Chen, B.; Fu, W.; Wang, Y.; Guo, D.; Wei, Z.; Xu, X.; Mendelsohn, F.O. Transplantation of purified CD34+ cells in the treatment of critical limb ischemia. J. Vasc. Surg. 2013, 58, 404-411 e3. [CrossRef]

158. Fujita, Y.; Kinoshita, M.; Furukawa, Y.; Nagano, T.; Hashimoto, H.; Hirami, Y.; Kurimoto, Y.; Arakawa, K.; Yamazaki, K.; Okada, Y.; et al. Phase II clinical trial of CD34+ cell therapy to explore endpoint selection and timing in patients with critical limb ischemia. Circ. J. 2014, 78, 490-501. [CrossRef] [PubMed]

159. Powell, R.J.; Marston, W.A.; Berceli, S.A.; Guzman, R.; Henry, T.D.; Longcore, A.T.; Stern, T.P.; Watling, S.; Bartel, R.L. Cellular therapy with Ixmyelocel-T to treat critical limb ischemia: The randomized, double-blind, placebo-controlled RESTORE-CLI trial. Mol. Ther. 2012, 20, 1280-1286. [CrossRef]

160. Losordo, D.W.; Kibbe, M.R.; Mendelsohn, F.; Marston, W.; Driver, V.R.; Sharafuddin, M.; Teodorescu, V.; Wiechmann, B.N.; Thompson, C.; Kraiss, L.; et al. A randomized, controlled pilot study of autologous CD34+ cell therapy for critical limb ischemia. Circ. Cardiovasc. Interv. 2012, 5, 821-830. [CrossRef] 
161. Liotta, F.; Annunziato, F.; Castellani, S.; Boddi, M.; Alterini, B.; Castellini, G.; Mazzanti, B.; Cosmi, L.; Acquafresca, M.; Bartalesi, F.; et al. Therapeutic Efficacy of Autologous Non-Mobilized Enriched Circulating Endothelial Progenitors in Patients With Critical Limb Ischemia- The SCELTA Trial. Circ. J. 2018, 82, 1688-1698. [CrossRef]

162. Fang, G.; Jiang, X.; Fang, Y.; Pan, T.; Liu, H.; Ren, B.; Wei, Z.; Gu, S.; Chen, B.; Jiang, J.; et al. Autologous peripheral blood-derived stem cells transplantation for treatment of no-option angiitis-induced critical limb ischemia: 10-year management experience. Stem. Cell Res. Ther. 2020, 11, 458. [CrossRef] [PubMed]

163. Sharma, S.; Pandey, N.N.; Sinha, M.; Kumar, S.; Jagia, P.; Gulati, G.S.; Gond, K.; Mohanty, S.; Bhargava, B. Randomized, DoubleBlind, Placebo-Controlled Trial to Evaluate Safety and Therapeutic Efficacy of Angiogenesis Induced by Intraarterial Autologous Bone Marrow-Derived Stem Cells in Patients with Severe Peripheral Arterial Disease. J. Vasc. Interv. Radiol. 2021, 32, 157-163. [CrossRef] [PubMed]

164. Rutherford, R.B.; Becker, G.J. Standards for evaluating and reporting the results of surgical and percutaneous therapy for peripheral arterial disease. Radiology 1991, 181, 277-281. [CrossRef] [PubMed]

165. Kusumanto, Y.H.; van Weel, V.; Mulder, N.H.; Smit, A.J.; van den Dungen, J.J.; Hooymans, J.M.; Sluiter, W.J.; Tio, R.A.; Quax, P.H.; Gans, R.O.; et al. Treatment with intramuscular vascular endothelial growth factor gene compared with placebo for patients with diabetes mellitus and critical limb ischemia: A double-blind randomized trial. Hum. Gene. Ther. 2006, 17, 683-691. [CrossRef]

166. Dong, Z.; Pan, T.; Fang, Y.; Wei, Z.; Gu, S.; Fang, G.; Liu, Y.; Luo, Y.; Liu, H.; Zhang, T.; et al. Purified CD34(+) cells versus peripheral blood mononuclear cells in the treatment of angiitis-induced no-option critical limb ischaemia: 12-Month results of a prospective randomised single-blinded non-inferiority trial. EBioMedicine 2018, 35, 46-57. [CrossRef]

167. Carstens, M.H.; Zelaya, M.; Calero, D.; Rivera, C.; Correa, D. Adipose-derived stromal vascular fraction (SVF) cells for the treatment of non-reconstructable peripheral vascular disease in patients with critical limb ischemia: A 6-year follow-up showing durable effects. Stem. Cell Res. 2020, 49, 102071. [CrossRef] [PubMed]

168. Guerin, C.L.; Loyer, X.; Vilar, J.; Cras, A.; Mirault, T.; Gaussem, P.; Silvestre, J.S.; Smadja, D.M. Bone-marrow-derived very small embryonic-like stem cells in patients with critical leg ischaemia: Evidence of vasculogenic potential. Thromb. Haemost. 2015, 113, 1084-1094. [CrossRef] [PubMed]

169. Yoder, M.C.; Ingram, D.A. Endothelial progenitor cell: Ongoing controversy for defining these cells and their role in neoangiogenesis in the murine system. Curr. Opin. Hematol. 2009, 16, 269-273. [CrossRef]

170. Ohtake, T.; Mochida, Y.; Ishioka, K.; Oka, M.; Maesato, K.; Moriya, H.; Hidaka, S.; Higashide, S.; Ioji, T.; Fujita, Y.; et al. Autologous Granulocyte Colony-Stimulating Factor-Mobilized Peripheral Blood CD34 Positive Cell Transplantation for Hemodialysis Patients with Critical Limb Ischemia: A Prospective Phase II Clinical Trial. Stem Cells Transl. Med. 2018, 7, 774-782. [CrossRef] [PubMed]

171. Povsic, T.J.; Zavodni, K.L.; Kelly, F.L.; Zhu, S.; Goldschmidt-Clermont, P.J.; Dong, C.; Peterson, E.D. Circulating progenitor cells can be reliably identified on the basis of aldehyde dehydrogenase activity. J. Am. Coll Cardiol. 2007, 50, 2243-2248. [CrossRef]

172. Gremmels, H.; Teraa, M.; Quax, P.H.; den Ouden, K.; Fledderus, J.O.; Verhaar, M.C. Neovascularization capacity of mesenchymal stromal cells from critical limb ischemia patients is equivalent to healthy controls. Mol. Ther. 2014, 22, 1960-1970. [CrossRef]

173. Fadini, G.P.; Sartore, S.; Schiavon, M.; Albiero, M.; Baesso, I.; Cabrelle, A.; Agostini, C.; Avogaro, A. Diabetes impairs progenitor cell mobilisation after hindlimb ischaemia-reperfusion injury in rats. Diabetologia 2006, 49, 3075-3084. [CrossRef] [PubMed]

174. Jialal, I.; Devaraj, S.; Singh, U.; Huet, B.A. Decreased number and impaired functionality of endothelial progenitor cells in subjects with metabolic syndrome: Implications for increased cardiovascular risk. Atherosclerosis 2010, 211, 297-302. [CrossRef]

175. Sibal, L.; Aldibbiat, A.; Agarwal, S.C.; Mitchell, G.; Oates, C.; Razvi, S.; Weaver, J.U.; Shaw, J.A.; Home, P.D. Circulating endothelial progenitor cells, endothelial function, carotid intima-media thickness and circulating markers of endothelial dysfunction in people with type 1 diabetes without macrovascular disease or microalbuminuria. Diabetologia 2009, 52, 1464-1473. [CrossRef] [PubMed]

176. Gu, Y.Q.; Zhang, J.; Guo, L.R.; Qi, L.X.; Zhang, S.W.; Xu, J.; Li, J.X.; Luo, T.; Ji, B.X.; Li, X.F.; et al. Transplantation of autologous bone marrow mononuclear cells for patients with lower limb ischemia. Chin. Med. J. 2008, 121, 963-967. [CrossRef] [PubMed]

177. Van Tongeren, R.B.; Hamming, J.F.; Fibbe, W.E.; Van Weel, V.; Frerichs, S.J.; Stiggelbout, A.M.; Van Bockel, J.H.; Lindeman, J.H. Intramuscular or combined intramuscular/intra-arterial administration of bone marrow mononuclear cells: A clinical trial in patients with advanced limb ischemia. J. Cardiovasc Surg. 2008, 49, 51-58.

178. Madaric, J.; Klepanec, A.; Valachovicova, M.; Mistrik, M.; Bucova, M.; Olejarova, I.; Necpal, R.; Madaricova, T.; Paulis, L.; Vulev, I. Characteristics of responders to autologous bone marrow cell therapy for no-option critical limb ischemia. Stem Cell Res. Ther. 2016, 7, 116. [CrossRef]

179. Jaluvka, F.; Ihnat, P.; Madaric, J.; Vrtkova, A.; Janosek, J.; Prochazka, V. Current Status of Cell-Based Therapy in Patients with Critical Limb Ischemia. Int. J. Mol. Sci. 2020, 21, 8999. [CrossRef] [PubMed]

180. Rigato, M.; Monami, M.; Fadini, G.P. Autologous Cell Therapy for Peripheral Arterial Disease: Systematic Review and MetaAnalysis of Randomized, Nonrandomized, and Noncontrolled Studies. Circ. Res. 2017, 120, 1326-1340. [CrossRef]

181. Gao, W.; Chen, D.; Liu, G.; Ran, X. Autologous stem cell therapy for peripheral arterial disease: A systematic review and meta-analysis of randomized controlled trials. Stem Cell Res. Ther. 2019, 10, 140. [CrossRef] [PubMed]

182. Peeters Weem, S.M.; Teraa, M.; de Borst, G.J.; Verhaar, M.C.; Moll, F.L. Bone Marrow derived Cell Therapy in Critical Limb Ischemia: A Meta-analysis of Randomized Placebo Controlled Trials. Eur. J. Vasc. Endovasc. Surg. 2015, 50, 775-783. [CrossRef] [PubMed] 
183. Makridakis, M.; Roubelakis, M.G.; Vlahou, A. Stem cells: Insights into the secretome. Biochim. Biophys. Acta 2013, 1834, 2380-2384. [CrossRef] [PubMed]

184. Xia, J.; Minamino, S.; Kuwabara, K.; Arai, S. Stem cell secretome as a new booster for regenerative medicine. Biosci. Trends. 2019, 13, 299-307. [CrossRef]

185. Baberg, F.; Geyh, S.; Waldera-Lupa, D.; Stefanski, A.; Zilkens, C.; Haas, R.; Schroeder, T.; Stuhler, K. Secretome analysis of human bone marrow derived mesenchymal stromal cells. Biochim. Biophys. Acta Proteins. Proteom. 2019, 1867, 434-441. [CrossRef] [PubMed]

186. Maffioli, E.; Nonnis, S.; Angioni, R.; Santagata, F.; Cali, B.; Zanotti, L.; Negri, A.; Viola, A.; Tedeschi, G. Proteomic analysis of the secretome of human bone marrow-derived mesenchymal stem cells primed by pro-inflammatory cytokines. J. Proteomics. 2017, 166, 115-126. [CrossRef] [PubMed]

187. Merfeld-Clauss, S.; Lupov, I.P.; Lu, H.; March, K.L.; Traktuev, D.O. Adipose Stromal Cell Contact with Endothelial Cells Results in Loss of Complementary Vasculogenic Activity Mediated by Induction of Activin A. Stem Cells 2015, 33, 3039-3051. [CrossRef]

188. Rubina, K.; Kalinina, N.; Efimenko, A.; Lopatina, T.; Melikhova, V.; Tsokolaeva, Z.; Sysoeva, V.; Tkachuk, V.; Parfyonova, Y Adipose stromal cells stimulate angiogenesis via promoting progenitor cell differentiation, secretion of angiogenic factors, and enhancing vessel maturation. Tissue. Eng. Part A 2009, 15, 2039-2050. [CrossRef]

189. Bhang, S.H.; Lee, S.; Shin, J.Y.; Lee, T.J.; Jang, H.K.; Kim, B.S. Efficacious and clinically relevant conditioned medium of human adipose-derived stem cells for therapeutic angiogenesis. Mol. Ther. 2014, 22, 862-872. [CrossRef]

190. Di Santo, S.; Yang, Z.; Wyler von Ballmoos, M.; Voelzmann, J.; Diehm, N.; Baumgartner, I.; Kalka, C. Novel cell-free strategy for therapeutic angiogenesis: In vitro generated conditioned medium can replace progenitor cell transplantation. PLoS ONE 2009, 4, e5643. [CrossRef] [PubMed]

191. Shrestha, C.; Zhao, L.; Chen, K.; He, H.; Mo, Z. Enhanced healing of diabetic wounds by subcutaneous administration of human umbilical cord derived stem cells and their conditioned media. Int. J. Endocrinol. 2013, 2013, 592454. [CrossRef]

192. Felice, F.; Piras, A.M.; Rocchiccioli, S.; Barsotti, M.C.; Santoni, T.; Pucci, A.; Burchielli, S.; Chiellini, F.; Ucciferri, N.; Solaro, R.; et al. Endothelial progenitor cell secretome delivered by novel polymeric nanoparticles in ischemic hindlimb. Int. J. Pharm. 2018, 542, 82-89. [CrossRef]

193. Takeuchi, R.; Katagiri, W.; Endo, S.; Kobayashi, T. Exosomes from conditioned media of bone marrow-derived mesenchymal stem cells promote bone regeneration by enhancing angiogenesis. PLoS ONE 2019, 14, e0225472. [CrossRef]

194. Mathiyalagan, P.; Liang, Y.; Kim, D.; Misener, S.; Thorne, T.; Kamide, C.E.; Klyachko, E.; Losordo, D.W.; Hajjar, R.J.; Sahoo, S. Angiogenic Mechanisms of Human CD34(+) Stem Cell Exosomes in the Repair of Ischemic Hindlimb. Circ. Res. 2017, 120, 1466-1476. [CrossRef] [PubMed]

195. Kir, D.; Schnettler, E.; Modi, S.; Ramakrishnan, S. Regulation of angiogenesis by microRNAs in cardiovascular diseases. Angiogenesis 2018, 21, 699-710. [CrossRef]

196. Welten, S.M.; Bastiaansen, A.J.; de Jong, R.C.; de Vries, M.R.; Peters, E.A.; Boonstra, M.C.; Sheikh, S.P.; La Monica, N.; Kandimalla E.R.; Quax, P.H.; et al. Inhibition of 14q32 MicroRNAs miR-329, miR-487b, miR-494, and miR-495 increases neovascularization and blood flow recovery after ischemia. Circ Res. 2014, 115, 696-708. [CrossRef] [PubMed]

197. Gong, M.; Yu, B.; Wang, J.; Wang, Y.; Liu, M.; Paul, C.; Millard, R.W.; Xiao, D.S.; Ashraf, M.; Xu, M. Mesenchymal stem cells release exosomes that transfer miRNAs to endothelial cells and promote angiogenesis. Oncotarget 2017, 8, 45200-45212. [CrossRef] [PubMed] 